Document downloaded from:

http://hdl.handle.net/10251/37361

This paper must be cited as:

Santos Figueroa, LE.; Moragues Pons, ME.; Raposo, MMM.; Batista, RM.; Costa, SPG.; Ferreira, RCM.; Sancenón Galarza, F.... (2012). Synthesis and evaluation of thiosemicarbazones functionalized with furylmoieties as new chemosensors for anion recognition. Organic and Biomolecular Chemistry. 10(36):7418-7428.

doi:10.1039/c2ob26200b.

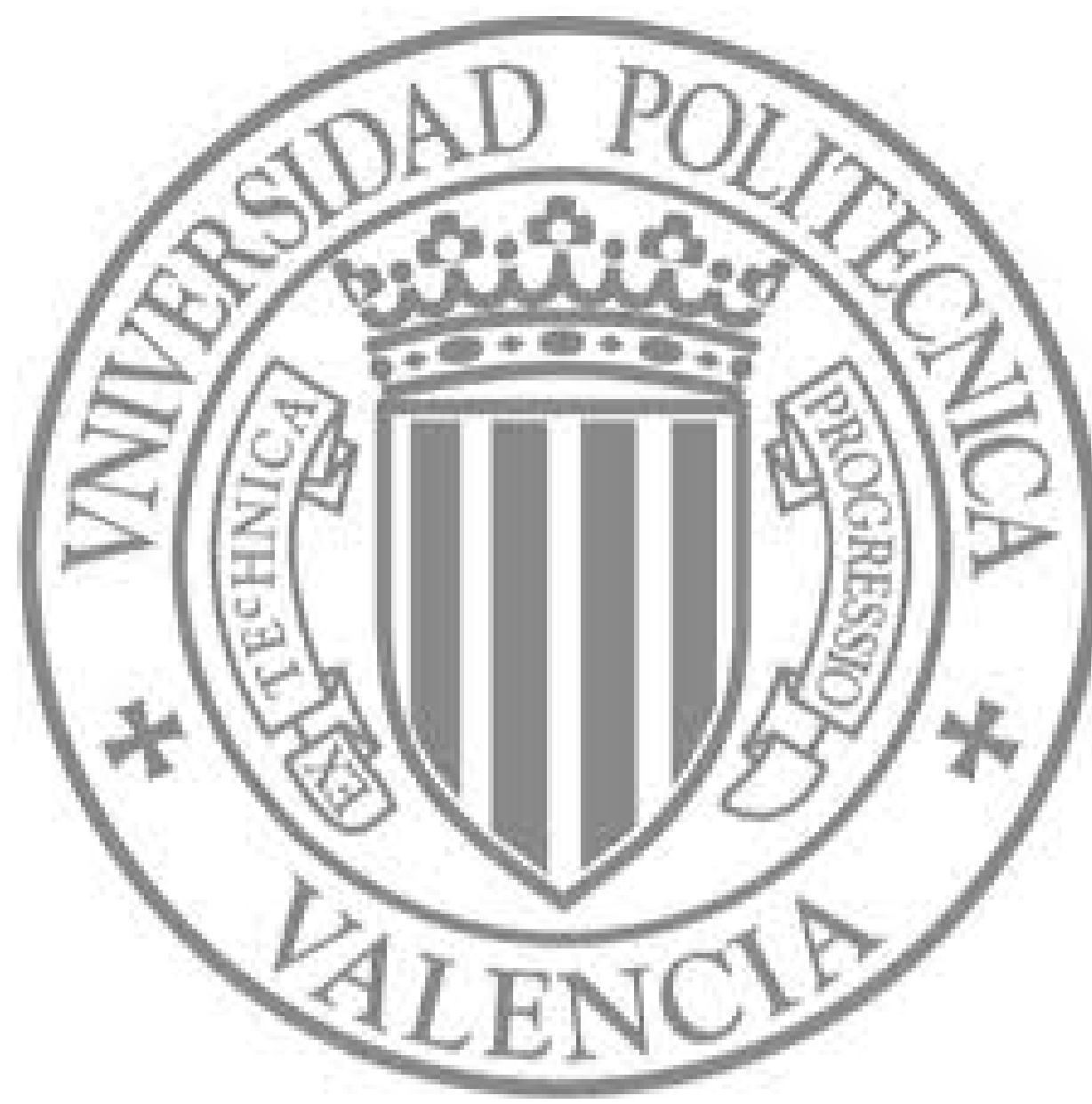

The final publication is available at

http://dx.doi.org/doi:10.1039/c2ob26200b

Copyright Royal Society of Chemistry 


\title{
Synthesis and Evaluation of Thiosemicarbazones Functionalized with Furyl Moieties as New Chemosensors for Anion Recognition
}

\author{
Luis E. Santos-Figueroa, ${ }^{a, b}$ María E. Moragues, ${ }^{a, b}$ M. Manuela M. Raposo, ${ }^{* c}$ Rosa M. F. Batista, ${ }^{c}$ Susana \\ P. G. Costa, ${ }^{c}$ Félix Sancenón, ${ }^{a, b}$ Ramón Martínez-Máñez, ${ }^{* a b}$ José Vicente Ros-Lis, ${ }^{a, b}$ Juan Soto ${ }^{a}$ \\ 5 Received (in $X X X, X X X)$ Xth $X X X X X X X X X 20 X X$, Accepted Xth $X X X X X X X X X 20 X X$ \\ DOI: 10.1039/b000000x
}

\begin{abstract}
A family of heterocyclic thiosemicarbazone dyes (3a-f and 4) containing furyl groups were synthesized in good yields, characterized and their response in acetonitrile in the presence of selected anions was studied. Acetonitrile solutions of 3a-f and $\mathbf{4}$ show absorption bands in the 335-396 nm range which are 10 modulated by the electron donor or acceptor strength of the heterocyclic systems appended to the thiosemicarbazone moiety. Anions fluoride, chloride, bromide, iodide, dihydrogen phosphate, hydrogen sulphate, nitrate, acetate and cyanide were used in recognition studies. From these anions, only sensing features were seen for fluoride, cyanide, acetate and dihydrogen phosphate. Two clearly different chromo-fluorogenic behaviours were observed, (i) a low shift of the absorption band due to the 15 coordination of the anions with the thiourea protons and (ii) the appearance of a new red shifted band due to deprotonation. For the latter effect, a change in the colour solution from pale yellow to purple was observed. Fluorescence studies were also in agreement with the different effects observed in the UV/Vis titrations. In this case, hydrogen bonding interactions were visible through the enhancement of the emission band, whereas deprotonation induced the appearance of a new red-shifted emission. Logarithms 20 of Stability Constants for the two processes (complex formation + deprotonation) for receptors 3a-f in the presence of fluoride and acetate anions were determined from spectrophotometric titrations using the HypSpec V1.1.18 program. Semi-empirical calculations to evaluate the hydrogen-donating ability of the receptors and a prospective electrochemical characterization of compound $3 \mathbf{b}$ in the presence of fluoride were also performed.
\end{abstract}

\section{${ }_{25}$ Introduction}

The development of new molecular systems for the detection of anions, cations or neutral molecules has gained prime importance in recent years due to the significance of detecting target species in biological and environmental samples. In this area, designed 30 receptors are able to transform, upon coordination, host-guest interactions into a measurable signal which allows analyte recognition and sensing through optical or electrochemical responses. ${ }^{1}$ In particular, optical outputs are attractive given the possibility of using low-cost, widely available instrumentation.

35 Apart from the development of fluorescent probes, chromogenic recognition has drawn attention because it offers the possibility of straightforward semiquantitative "naked-eye" detection. ${ }^{2}$ Moreover, the colorimetric probes showing a simple displacement of the absorption band allow to develop ratiometric

${ }^{a}$ Centro de Reconocimiento Molecular y Desarrollo Tecnológico (IDM), Unidad Mixta Universidad de Valencia-Universidad Politécnica de Valencia. Camino de Vera s/n, 46022 Valencia, Spain. E-mail: rmaez@qim.upv.es

${ }^{b}$ CIBER de Bioingeniería, Biomateriales y Nanomedicina (CIBER-BBN).

${ }^{c}$ Centro de Química, Universidade do Minho, Campus de Gualtar, 4710057 Braga,Portugal.E-mail: mfox@quimica.uminho.pt
40 methods, thus avoiding the use of an internal reference. Optical detection for metal cations was developed more than two decades ago, ${ }^{3}$ yet anionic chromogenic receptors have only recently been investigated. ${ }^{4}$ The latter focus on anions and are mainly due to the more challenging chemistry of host-anion interactions given the 45 usually lower stability constants observed with anionic species when compared with metal cations, the complex and varied shapes found for anions, their possible dependence on $\mathrm{pH}$ and the strong competition of water usually found for receptor-anion complexes based on hydrogen-bonding interactions. ${ }^{5}$

50 Despite these setbacks, the supramolecular chemistry of anions has advanced a great deal in the last few years mainly due to the progress made in the knowledge of how the formation of hostanion complexes operates. Based on these advances, a number of receptors for anion binding have been developed, most of which ${ }_{55}$ are based on hydrogen bonding and electrostatic interactions. ${ }^{6}$ In contrast to purely electrostatic interactions, which are only distance-dependent, hydrogen bonds offer the advantage of being directional which allows to discriminate between anions of different geometries or hydrogen-bonding requirements. ${ }^{7}$ Among 60 the neutral anion binding groups, thioureas and thioureacontaining fragments have been widely used for the formation of complexes with anions because the hydrogen-bonding ability of 
these functional groups commonly results in the formation of quite stable complexes, and also because they can be easily synthesized from commercially available reagents by a singlestep procedure. ${ }^{8}$ In fact, thiourea derivatives have been the 5 subject of intense research given their performance in the development of anion receptors and, for instance, thioureas (and also ureas) have been demonstrated as good coordinating groups for Y-shaped anions such as carboxylates. ${ }^{9}$ Moreover, the hydrogen-bonding ability of the thiourea moiety depends on the 10 acidity of the thioureido $\mathrm{NH}$ protons and the number of binding sites. A means of tuning this acidity is to introduce electrondonating or electron-withdrawing substituents. ${ }^{10}$ Additionally, experimental and theoretical studies have demonstrated that replacing the benzene ring of a chromophore bridge with easily 15 delocalizable five-member heteroaromatic rings, such as thiophene, pyrrole and thiazole, results in an enhanced intramolecular electronic delocalization. ${ }^{11}$

On the other hand, among the molecules containing thiourea fragments the use of thiosemicarbazones has recently gained 20 interest as potential receptors. Schiff base compounds containing thiosemicarbazone groups have also grown in the biology and chemistry areas due to ample biological activity, ${ }^{12}$ such as antitumour, fungicidal, bactericidal, or antiviral, and nonlinear optical properties. ${ }^{13}$ Moreover thiosemicarbazones have also 25 gained attention recently as anion receptors due to their ease synthesis. Also, thiosemicarbazones will be easily included in aromatic frameworks functionalized with acceptor and donor moieties in order to fine tune the acidity of the N-H protons. In fact, we and others have recently demonstrated that $\pi$-conjugated 30 heterocyclic derivatives, containing thiosemicarbazone moieties, are suitable systems for the colorimetric and fluorimetric sensing of anions. ${ }^{14}$ Following this previous work on the synthesis and evaluation of thiosemicarbazones as binding groups, and by also considering our interest in the development of new probes for

35 anion recognition, we report herein the synthesis and the characterization of new $N$-phenylthiosemicarbazones. As a special feature, these newly reported derivatives additionally contain heteroaromatic $\pi$-conjugated systems (instead of the more commonly used benzene rings) because anion chemosensors

40 containing phenylthioureas functionalized with heterocyclic moieties are still unusual. The new reported receptors contain furan (instead of thiophene as we have reported recently) ${ }^{14}$ as aromatic rings. The underlying idea of the present paper was to evaluate the effect in the binding efficiency of the 45 thiosemicarbazone moiety upon functionalization with furan groups.

\section{Results and Discussion.}

\section{Synthesis and characterization}

Different formyl precursors 1a-g containing several 50 substituents, such as bromo, nitro and alkoxy, linked to different $\pi$ conjugating bridges were used to evaluate the influence of the structure modification (i.e., donating and accepting strength of these groups, and the nature and length of the $\pi$-conjugated bridge) of the optical properties of prepared $\mathrm{N}$ 55 phenylthiosemicarbazones 3a-f and 4. The new compounds containing furan and arylfuran $\pi$-conjugated bridges were synthesized in good yields (76-96\%) through the Schiff-base condensation of heterocyclic aldehydes 1a-g with 4-phenyl-3thiosemicarbazide in methanol at room temperature (see Scheme 60 1).

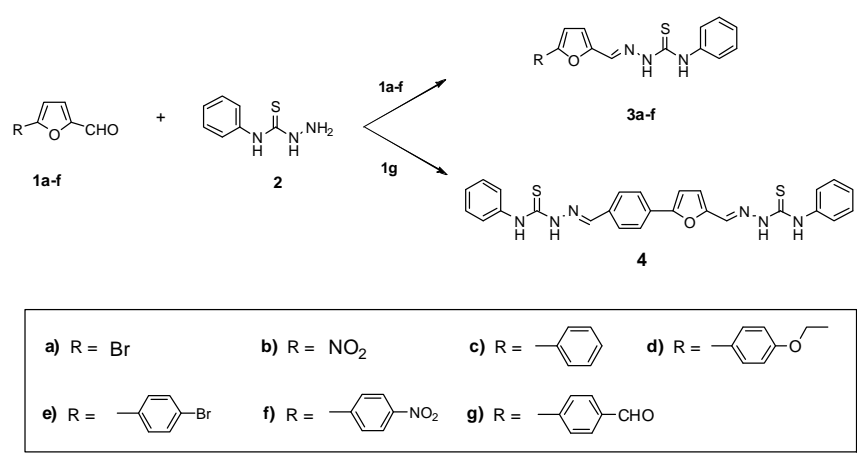

Scheme 1 Synthesis of furyl-thiosemicarbazone receptors $3 a-f$ and 4

Aldehydes 1a-c and 1e-f are inexpensive and commercially available, and 5-(4'-ethoxyphenyl)furan-2-carbaldehyde $\mathbf{1 d}^{15}$ and 65 the precursor 5-(4'-formylphenyl)furan-2-carbaldehyde $\mathbf{1 g}$ are easily prepared in good yields (75-91\%) through Suzuki crosscoupling reactions of 5-bromofuran-2-carbaldehyde with 4ethoxyphenylboronic acid or 4-formylphenylboronic acid, respectively, using the synthetic procedure previously reported by 70 us. ${ }^{11 a}$ All the compounds were completely characterized by ${ }^{1} \mathrm{H}$ and ${ }^{13} \mathrm{C}$ NMR, IR, MS, EA or HRMS, and the data obtained were in full agreement with the proposed formulation (see experimental section). The ${ }^{1} \mathrm{H}$ NMR spectra of this family of thiosemicarbazones show the most characteristic signals for $\mathrm{N}-\mathrm{H}$ 75 and $\mathrm{CH}=\mathrm{N}$ protons. ${ }^{1} \mathrm{H}$ NMR studies using deuterated $\mathrm{N}, \mathrm{N}$ dimethylsulphoxide (DMSO) displayed resonances due to the $\mathrm{CH}=\mathrm{N}$ protons in the $7.99-8.16 \mathrm{ppm}$ interval, whereas thiourea $\mathrm{N}$ $\mathrm{H}$ protons were found in the 9.88-10.18 and 11.84-12.23 ppm range for the $\mathrm{N}-\mathrm{H}$ groups adjacent to the monosubstituted phenyl 80 ring and for the $\mathrm{N}-\mathrm{H}$ adjacent to the $\mathrm{CH}=\mathrm{N}$ moiety, respectively. When the whole family of compounds was considered, the highest variations in $\delta$ were found for the $\mathrm{N}-\mathrm{H}$ protons located in the vicinity of the $\mathrm{CH}=\mathrm{N}$ moiety adjacent to the furan ring functionalized with electron withdrawing or electron donor ${ }_{85}$ groups $(\Delta \delta=0.39 \mathrm{ppm})$. Additionally, the $\mathrm{CH}=\mathrm{N}$ protons were the least affected by the substituents located in their vicinity $(\Delta \delta$ $=0.17 \mathrm{ppm})$, whereas the $\mathrm{N}-\mathrm{H}$ protons adjacent to the monosubstituted phenyl ring showed an interval of $\Delta \delta=0.30$ ppm.

\section{Spectroscopic Behaviour of 3 a-f and 4.}

Table 1. Spectroscopic Data for Compounds 3a-f and 4

\begin{tabular}{ccccccccc}
\hline Receptor & $\begin{array}{c}\lambda_{\mathrm{ab}} \mathrm{LH} \\
(\mathrm{nm})\end{array}$ & $\begin{array}{c}\lambda_{\mathrm{ab}} \mathrm{L}^{-} \\
(\mathrm{nm})^{\mathrm{a}}\end{array}$ & $\begin{array}{c}\mathrm{Log} \varepsilon \\
(\mathrm{LH})\end{array}$ & $\begin{array}{c}\lambda_{\mathrm{em}} \mathrm{LH} \\
(\mathrm{nm})\end{array}$ & $\begin{array}{c}\lambda_{\mathrm{em}} \mathrm{L}^{-} \\
(\mathrm{nm})^{\mathrm{a}}\end{array}$ & $\Phi$ & $\begin{array}{c}\Delta \lambda_{\text {ab-em }} \\
\mathrm{LH} \\
(\mathrm{nm})\end{array}$ & $\begin{array}{c}\Delta v_{\text {ab-em }} \\
\mathrm{LH} \\
\left(\mathrm{cm}^{-1}\right)\end{array}$ \\
\hline 3a & 335 & 391 & 4.55 & 421 & 431 & 0.0016 & 86 & 6097.78 \\
3b & 383 & 540 & 4.27 & 422 & 409 & 0.0006 & 39 & 2412.98 \\
3c & 362 & 416 & 4.59 & 426 & 491 & 0.0226 & 64 & 4150.13 \\
3d & 366 & 410 & 4.01 & 432 & 462 & 0.0644 & 66 & 4174.26 \\
3e & 364 & 423 & 4.61 & 429 & 476 & 0.0183 & 65 & 4162.50 \\
3f & 396 & 489 & 4.31 & 586 & 546 & 0.0259 & 190 & 8187.68 \\
4 & 359 & 443 & 4.53 & 486 & 467 & 0.0363 & 127 & 7279.02 \\
\hline
\end{tabular}

${ }^{\mathrm{a}}$ Measured upon addition of 100 equivalents of fluoride anion. 
Acetonitrile solutions $\left(\mathrm{C}=1.2 \times 10^{-5} \mathrm{~mol} \mathrm{dm}^{-3}\right.$ at $\left.25^{\circ} \mathrm{C}\right)$ of thiosemicarbazone-functionalised receptors 3a-f and $\mathbf{4}$ showed an intense absorption band $(\log \varepsilon \approx 4.4)$ in the $335-396 \mathrm{~nm}$ region (see Table 1 for spectroscopic data). Compound 3a, containing 5 the thiosemicarbazone moiety and surrounded by a phenyl and a furyl ring functionalized with a bromo group, presented an absorption band at $335 \mathrm{~nm}$, whereas changing the bromo substituent for a better electron acceptor moiety, such as a nitro group (receptor $\mathbf{3 b}$ ), induced a pronounced red shift from 335 to $10383 \mathrm{~nm}$. The coupling of an additional aromatic ring with the framework of $\mathbf{3 a}$ or $\mathbf{3 b}$ (receptors $\mathbf{3 e}$ and $\mathbf{3 f}$, respectively) induced a significant bathochromic shift of the band (from 335 to $364 \mathrm{~nm}$ and from 383 to $396 \mathrm{~nm}$, respectively), this being a direct consequence of the extension of the conjugation.

\section{UV-Vis Studies Involving Anions.}

The UV-Vis behaviour of receptors 3a-f and $\mathbf{4}$ in acetonitrile solutions $\left(\mathrm{C}=1.2 \times 10^{-5} \mathrm{~mol} \mathrm{dm}^{-3}\right)$ was studied at $25^{\circ} \mathrm{C}$ in the presence of selected anions of different sizes and shapes such as 20 fluoride, chloride, bromide, iodide, cyanide, nitrate, acetate, perchlorate, hydrogen sulphate and dihydrogen phosphate. For all the receptors, addition of increasing quantities (up to 10 equiv) of chloride, bromide, iodide, nitrate, perchlorate and hydrogen sulphate induced negligible changes in the UV-Vis bands, which 25 clearly indicates that no coordination occurs. Much more relevant results were observed in the presence of those anions showing a basic character in acetonitrile, such as fluoride, cyanide, acetate, and dihydrogen phosphate (see Figure 1). The changes in colour observed upon addition of basic anions were almost immediate 30 (see Supporting Information for the kinetic profile of changes in the $390 \mathrm{~nm}$ band of $\mathbf{3 b}$ in the presence of fluoride anion).

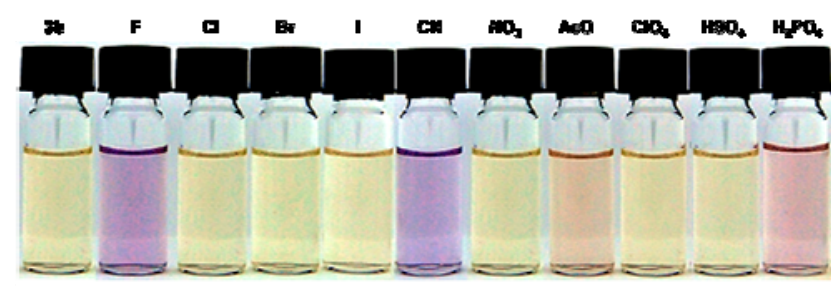

Figure 1. Colour changes of the $3 \mathbf{b}$ solution $\left(1.2 \times 10^{-4} \mathrm{~mol} \mathrm{dm}^{-3}\right)$ seen in the presence of 10 equiv. of $\mathrm{F}^{-}, \mathrm{Cl}^{-}, \mathrm{Br}^{-}, \mathrm{I}^{-}, \mathrm{CN}^{-}, \mathrm{NO}_{3}^{-}, \mathrm{AcO}^{-}, \mathrm{ClO}_{4}^{-}, \mathrm{HSO}_{4}^{-}$ 35 and $\mathrm{H}_{2} \mathrm{PO}_{4}{ }^{-}$

In most cases, UV-vis titration experiments with receptors 3a-f and $\mathbf{4}$ and fluoride showed a similar behaviour; i.e., intensity decreased and a slight hypsochromic shift of the absorption band, 40 together with a simultaneous growth of a new red-shifted band. However, it was clearly apparent from the titration profiles that both the position of the new band and the relative intensity of the absorption band of the receptor in relation to the red-shifted band upon addition of fluoride were dependent on the receptor used.

45 Acetonitrile solutions of $\mathbf{3 b}$ were yellow due to the presence of a band at $383 \mathrm{~nm}$. Upon addition of increasing quantities of the fluoride anion, this band progressively decreased, while a new absorption at $540 \mathrm{~nm}(\Delta \lambda=157 \mathrm{~nm})$ increased in intensity with a clear isosbestic point at $429 \mathrm{~nm}$ (see Figure 2). The formation of 50 this new visible band induced a change in colour from pale yellow to purple (see Figure 1).

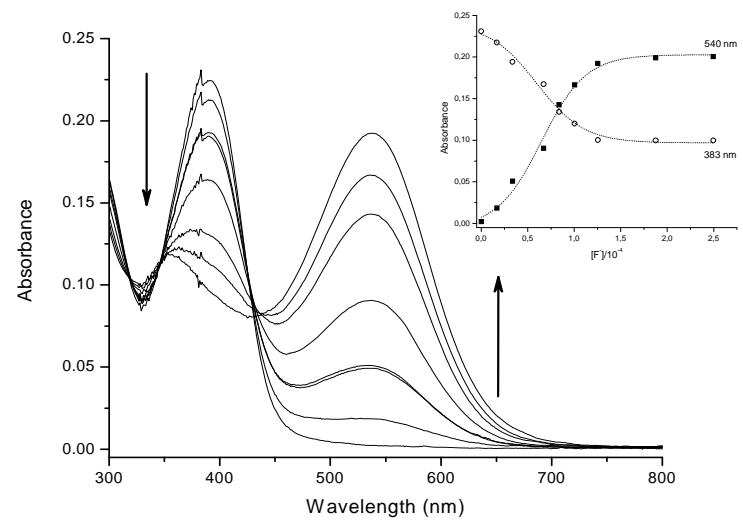

Figure 2. UV-Vis titration of receptor $3 \mathbf{b}\left(1.2 \times 10^{-5} \mathrm{~mol} \mathrm{dm}^{-3}\right)$ with fluoride anion ( $0-10$ equiv.) in acetonitrile. Inset: Absorbance of solution of $3 \mathbf{b}$ at 383 and $540 \mathrm{~nm}$ versus concentration of fluoride $\left(\mathrm{mol} \mathrm{dm}^{-3}\right)$.

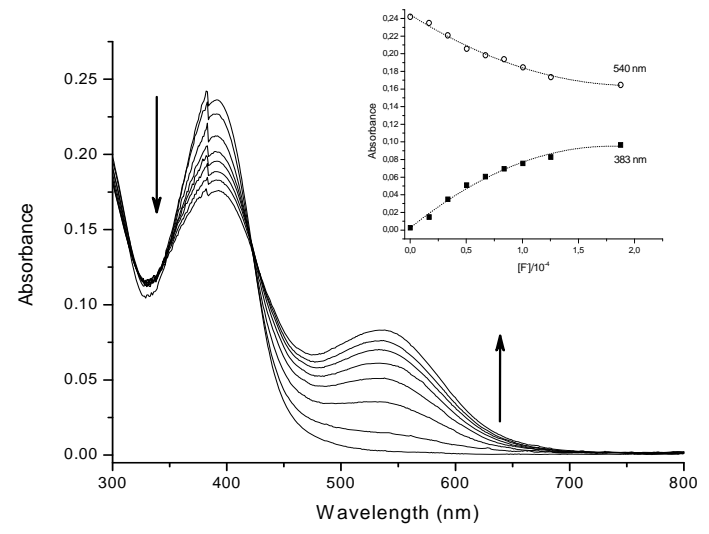

${ }_{55}$ Figure 3. UV-Vis titration of receptors $3 \mathbf{b}\left(1.2 \times 10^{-5} \mathrm{~mol} \mathrm{dm}^{-3}\right)$ with acetate anion ( $0-10$ equiv.) in acetonitrile. Inset: Absorbance of acetonitrile solutions of receptor $3 \mathbf{b}$ at 383 and $540 \mathrm{~nm}$ versus concentration of acetate anion $\left(\mathrm{mol} \mathrm{dm}^{-3}\right)$.

60 Fluoride and cyanide anions were able to induce UV-Vis changes for all the receptors tested, whereas acetate and hydrogen phosphate displayed a poorer response with all the receptors (see Figure 3).

The selectivity of receptors 3a-b and $\mathbf{4}$ for the most basic anion ${ }_{65}\left(\mathrm{~F}^{-}, \mathrm{CN}^{-}, \mathrm{AcO}^{-}\right.$and $\left.\mathrm{H}_{2} \mathrm{SO}_{4}^{-}\right)$was demonstrated by further UVvisible experiments. Figure 4 shows that addition of 10 equiv. of fluoride anion to acetonitrile solutions of receptor $3 \mathbf{b}$ induced the appearance of an absorbance band at $540 \mathrm{~nm}$. The same redshifted band with identical absorbance was obtained upon 70 addition of a mixture of anions (10 equiv. of fluoride, chloride, bromide, iodide, perchlorate, hydrogen sulfate and nitrate). Similar chromogenic behaviors were observed for $\mathrm{CN}^{-}$and $\mathrm{AcO}^{-}$ in mixtures with other anions (i.e. chloride, bromide, iodide, perchlorate, hydrogen sulfate and nitrate).

75 Once determined the selectivity of this family of receptors the limits of detection (LOD) were estimated. In all cases LOD values of ca. $10 \mu \mathrm{M}$ were determined for fluoride and cyanide anions 


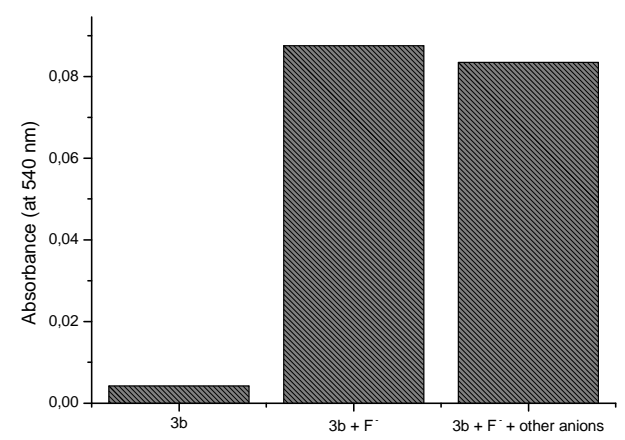

Figure 4. Absorbance at $540 \mathrm{~nm}$ of receptor $3 \mathbf{b}\left(1.0 \times 10^{-5} \mathrm{~mol} \mathrm{dm}^{-3}\right)$ alone and upon addition of 10 equiv. of fluoride and 10 equivalents of fluoride, chloride, bromide, perchlorate, hydrogen sulphate, iodide and nitrate anions.

Moreover the interaction of 3a-f and $\mathbf{4}$ with basic anions in water and acetonitrile-water mixtures (1:1, 5:1 and 10:1 v/v) was also tested. Unfortunately in all cases neither changes in colour nor in fluorescence were observed. This was most likely due to 10 the reduced basicity of the anions in aqueous environments due to solvation and the poor acidity of the receptors when compared with other reported ligands (vide infra).

On the whole, the changes observed in acetonitrile are in agreement with the expectation that the interaction between an 15 electron-rich anion and a donor group in a push-pull system will induce a bathochromic shift. In fact, similar shifts in the presence of fluoride have also been reported to occur using other amide-, urea-, thiourea-, or pyrrole-containing hosts. ${ }^{16}$ This interaction is attributed to the formation of strong hydrogen-bonding 20 complexes between these groups and to the highly basic $\mathrm{F}^{-}$anion that is eventually able to originate the deprotonation of the binding site. ${ }^{17}$ In fact, we believe that this dual complex + deprotonation process is active in all of our receptors in the presence of fluoride: a first step consisting in the formation of a 25 hydrogen-bonding complex and a second step in which the receptor is deprotonated by the anion. Usually the formation of hydrogen-bonding complexes, via receptor-interactions, is reflected in relatively minor variations in the absorption band of the receptor, whereas the deprotonation processes are revealed 30 with the clear appearance of a new absorption band at longer wavelengths. ${ }^{18}$ From a more physical viewpoint, the negative charge generated upon deprotonation induces an increase in the intensity of the electrical dipole that results in a substantial red shift of the absorption band. In most cases, the observation of 35 complexation or/and deprotonation depends on a delicate balance between the acidity of the $\mathrm{N}-\mathrm{H}$ protons of the receptor and the basicity of the anion. In our case, a close look at the results indicated that the final response of receptors $3 \mathbf{a}-\mathbf{f}$ and $\mathbf{4}$ to the tested basic anions strongly depends on the chemical nature of the

40 functional groups attached to the thiosemicarbazone framework, which modulated the acidity of the N-H protons; i.e. for a certain anion (fluoride) at a given concentration, the development of the band due to deprotonation grew more or less in intensity depending on the receptors used.

45 When comparing the behaviour of similar compounds 3a-f, it was apparent that the presence of electron-withdrawing moieties, such as a nitro group in $\mathbf{3 b}$ and $\mathbf{3 f}$, induced an increase in the acidity of the $\mathrm{N}-\mathrm{H}$ protons of the thiosemicarbazone, thus favouring the interaction with the fluoride and cyanide anions and 50 deprotonation, whereas the presence of electron-donor groups, such as bromo (3a) and ethoxy (3d), respectively induced a certain decrease in acidity and the red-shifted band due to deprotonation developed to a lesser extent.

\section{${ }_{55}$ Stability Constants.}

As stated above in the interaction of basic anions with semithiocarbazone-containing receptors 3a-f and 4, two different behaviours could be expected; i.e., (i) hydrogen-bonding interactions and (ii) deprotonation (see Equations 1 and 2).

$$
\begin{gathered}
\mathrm{LH}+\mathrm{A}^{-} \leftrightarrows \mathrm{LH} \cdots \mathrm{A}^{-} \\
\mathrm{LH} \cdots \mathrm{A}^{-}+\mathrm{A}^{-} \leftrightarrows \mathrm{L}^{-}+\mathrm{A}_{2} \mathrm{H}^{-}
\end{gathered}
$$

In order to complete the characterization of the interaction of receptors 3a-f and $\mathbf{4}$ with anions, the strength of both processes 65 (coordination and deprotonation) was studied via the evaluation of the corresponding stability constants, which were determined by the UV-Vis spectroscopic titrations between receptors 3a-f and $\mathbf{4}$ and the fluoride and acetate anions using the HypSpec software V1.1.18. The data set was adjusted to the two 70 consecutive equilibriums in Equations 1 and 2; the results are shown in Table 2.

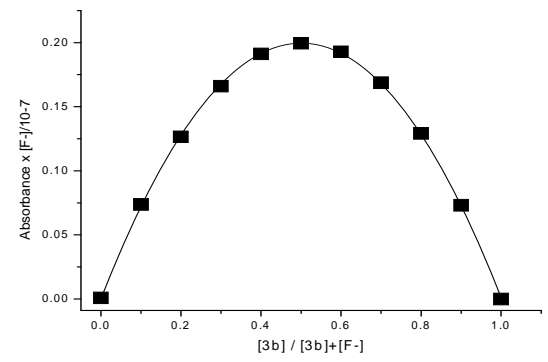

Figure 5. Job's plot for complexation of $\mathbf{3 b}$ with fluoride anion determined by UV-Vis spectrophotometry in acetonitrile at $383 \mathrm{~nm}$ and $[3 \mathbf{b}]+\left[\mathrm{F}^{-}\right]=1.2 \times 10^{-4} \mathrm{~mol} \mathrm{dm}^{-3}$

75

In all cases, the formation of anion/ligand 1:1 complexes shown in Equation 1 was confirmed for the method of continuous variation (Job's plots). As an example Figure 4 shows the studies for the interaction of $\mathbf{3 b}$ with fluoride (see also Supporting 80 Information for other receptors). It is noticeable that despite the presence of two potential binding sites in 4 the receptor showed the same response than $3 \mathrm{a}-\mathrm{f}$, namely the formation of $1: 1$ receptor-anion stoichiometry complexes (see Suppoting information for Job plot analysis).

85 Table 2 shows that, as a general trend, the logarithms of the stability constants measured for both equilibriums with fluoride were higher than those obtained for acetate. This is in agreement with the more basic character of fluoride in acetonitrile when compared with acetate. The logarithms of the stability constants 90 for the formation of the $\mathrm{Y}$-shaped hydrogen-bonding complexes were about one order of magnitude larger than the logarithms of the stability constants for the deprotonation for fluoride, and 
about three orders of magnitude larger for acetate. It is also apparent in Table 2 that the deprotonation logarithms of constants for all the receptors were more important for fluoride than for acetate.

Table 2. Logarithms of the stability constants measured for the interaction of receptors $\mathbf{3 a - f}$ with fluoride and acetate.

\begin{tabular}{|c|c|c|c|c|}
\hline & \multicolumn{2}{|c|}{$\mathbf{F}^{-}$} & \multicolumn{2}{|r|}{$\mathbf{A c}^{-}$} \\
\hline & $\mathbf{L H}+\mathbf{A}^{-} \leftrightarrows \mathbf{L H} \cdots \mathrm{A}^{-}$ & $\mathbf{L H} \cdots \mathrm{A}^{-}+\mathrm{A}^{-} \leftrightarrows \mathbf{L}^{-}+\mathrm{A}_{2} \mathrm{H}^{-}$ & $\mathbf{L H}+\mathrm{A}^{-} \leftrightarrows \mathbf{L H} \cdots \mathrm{A}^{-}$ & $\mathbf{L H} \cdots \mathrm{A}^{-}+\mathrm{A}^{-} \leftrightarrows \mathrm{L}^{-}+\mathrm{A}_{2} \mathrm{H}^{-}$ \\
\hline 3a & $3.46(6)$ & $2.48(7)$ & $3.40(6)$ & $0.31(8)$ \\
\hline $3 \mathbf{b}$ & $4.56(2)$ & $4.24(4)$ & $3.91(1)$ & $1.53(4)$ \\
\hline $3 c$ & $4.20(5)$ & $3.51(8)$ & $3.60(1)$ & $0.13(4)$ \\
\hline 3d & $4.23(4)$ & $3.81(8)$ & $-a$ & $-a$ \\
\hline $3 \mathbf{e}$ & $4.37(1)$ & $3.57(7)$ & $3.56(8)$ & $0.31(2)$ \\
\hline $3 f$ & $4.47(7)$ & $4.47(1)$ & $4.56(8)$ & $1.64(1)$ \\
\hline
\end{tabular}

${ }^{a}$ No reliable results were obtained.

10 The stability constants for the formation of the corresponding hydrogen-bonding complexes remained approximately the same for both anions. It is noteworthy that the logarithms of stability constants determined in this study for thiosemicarbazones were generally lower than those reported for the other urea/thiourea 15 receptors functionalized with benzene rings containing electron withdrawing moieties. This is a clear consequence of the reduced acidity of the receptors studied herein when compared with other reported ligands. For instance, compound 1,3-bis(4nitrophenyl)urea has also been reported to display the two-step

20 process (coordination + deprotonation) upon addition of fluoride with logarithms of the stability constants for the formation of the complex and for the deprotonation of 7.38 and 6.37 respectively. ${ }^{19}$ Another urea-based receptor (1nitrobenzo[1,2,5]oxadiazol-4-yl)-3-(4-nitrophenyl)urea showed

${ }_{25}$ logarithm values higher than 6 for the formation of the hydrogenbonding complexes and 4.2 for the deprotonation step. ${ }^{20}$ Finally, the thiourea receptor 1-(2-methyl-1,3-dioxo-2,3-dihydro- $1 H$ isoindol-5-yl)-3-phenylthiourea also underwent a first coordination step and a second proton transfer process with the 30 basic anions, with a logarithm of stability constants 5.7 and 5.5 for fluoride, and 6.02 and 3.23 for acetate. ${ }^{21}$

\section{Fluorogenic studies involving anions.}

It is widely known that fluorescence, despite being a less 35 extended technique in some cases, is much more sensitive to intermolecular interactions than colour changes. Therefore, fluorescence studies in acetonitrile solutions of the receptors upon addition of increasing amounts of the corresponding anion were carried out. Receptors were excited in the pseudo-isosbestic ${ }_{40}$ points observed in the course of UV-vis titrations. In all cases, the emission consisted in a broad, unstructured band. Quantum yields in acetonitrile (see Table 1) ranged from quite low (receptor 3a, $\Phi=0.0016$ ) to medium (compound $3 d, \Phi=0.0644$ ). For all the receptors tested (i.e., 3a-f and 4), addition of the anions chloride, 45 bromide, iodide, hydrogen sulphate and nitrate induced negligible changes in the emission intensity profiles. In contrast, the fluorescence emission in the presence of fluoride, cyanide, acetate and dihydrogen phosphate changed significantly.

A different general behaviour was found depending on the 50 anion and the receptor used in the studies. As a general trend, and in the presence of fluoride, all the receptors 3a-f and $\mathbf{4}$ showed enhanced fluorescence intensity upon the addition of moderate ounts of fluoride followed by a quenching of the emission band at higher anion concentrations and the growth of a new band at ${ }_{55}$ longer wavelengths ( $\lambda_{\mathrm{em}}$ in the $421-586 \mathrm{~nm}$ range, see Table 1$)$.
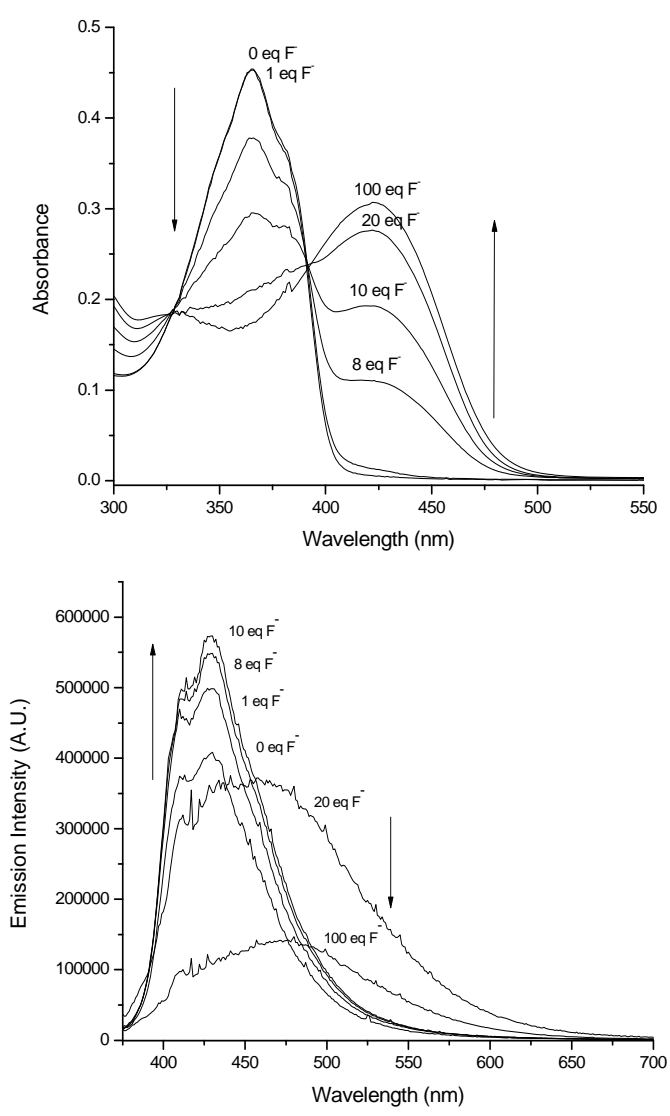

Figure 6. Interaction of receptor $3 \mathbf{e}\left(1.2 \times 10^{-5} \mathrm{~mol} \mathrm{dm}^{-3}\right)$ with the fluoride anion (top): absorption spectra and (bottom): emission spectra of receptor in the presence of $0,1,8,10,20$ and 100 eq. of fluoride anion

60 In order to interpret this behaviour, we made a comparison between the changes observed in the emission and absorption spectra. A typical example is that shown in Figure 6, that is, the behaviour found for ligand $\mathbf{3 e}$ in the presence of fluoride. As seen, for small quantities of fluoride anion, while the intensity of ${ }_{65}$ the absorption band at $364 \mathrm{~nm}$ remains unaltered, the fluorescence intensity at $429 \mathrm{~nm}$ progressively increased until 10 equivalents of fluoride had been added. Moreover, upon addition of larger amounts of fluoride, the intensity of the emission band at $429 \mathrm{~nm}$ diminished, suggesting the formation of a new 70 compound that emits at longer wavelengths $\left(\lambda_{\mathrm{em}}=476 \mathrm{~nm}\right)$. Thus, fluorescence measurements suggest that the interaction of the receptors with fluoride took place in two steps, as found in the UV-vis studies. In the first step, the anion coordinates with the acidic NH protons of the thiourea moiety through hydrogen- 
bonding interactions led to an increase in the donor capacity of the binding site. Upon addition of more equivalents of the anion, a deprotonation of the receptor occurred. This deprotonation process induced the appearance of the red-shifted visible and 5 emission bands.
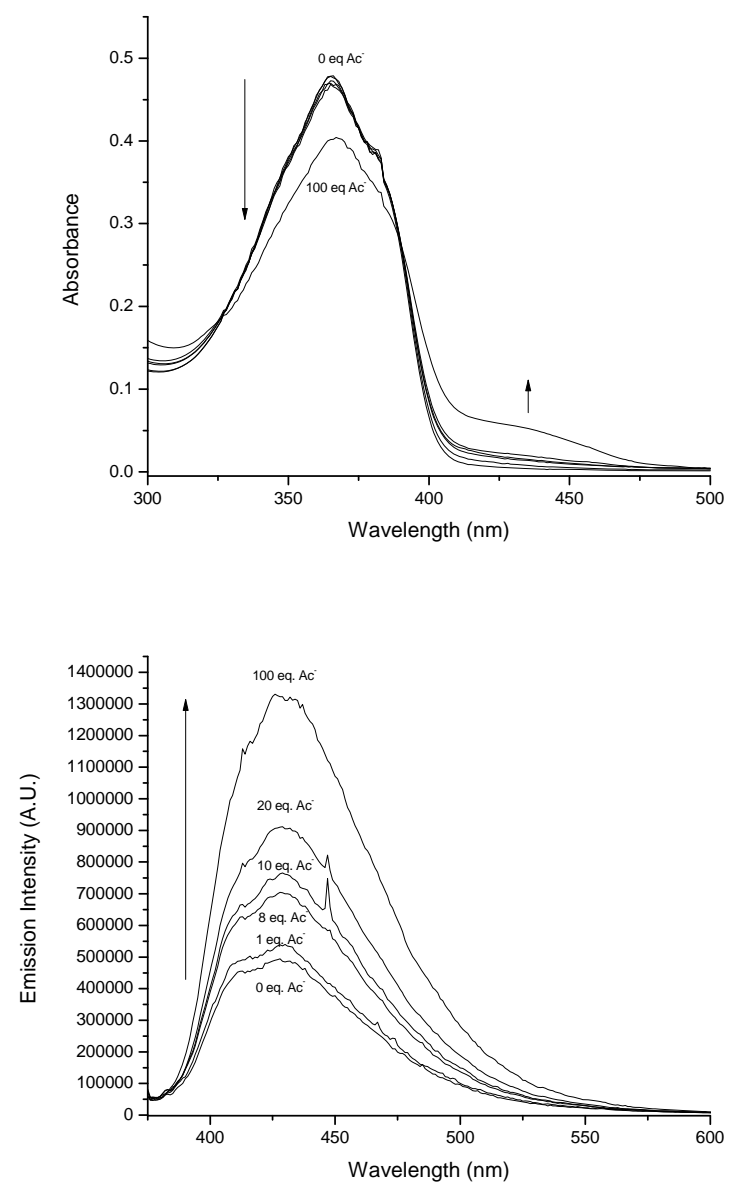

Figure 7. Interaction of receptor $3 \mathbf{e}\left(1.2 \times 10^{-5} \mathrm{~mol} \mathrm{dm}^{-3}\right)$ with the acetate anion (top): absorption spectra and (bottom): emission spectra of the receptor in the presence of $0,1,8,10,20$ and 100 eq. of the acetate anion.

The overall shape and intensity of the emission band for a certain receptor-anion pair depends on the $\mathrm{LH} / \mathrm{LH} \cdot \cdots \mathrm{A}^{-} / \mathrm{L}^{-}$ratios. For instance, a closer look at the titration experiments with fluoride indicated that in order to induce the appearance of the 15 red-shifted emission band, larger amounts of fluoride are required for receptor 3e (functionalized with bromophenylfuryl) than for receptor 3f (functionalized with nitrophenylfuryl), which is in agreement with the larger acidity of $\mathbf{3 f}$ versus $\mathbf{3 e}$.

Figure 7 shows the emission and absorption spectra for 20 receptor $3 \mathbf{e}$ in the presence of acetate. The emission intensity was enhanced upon the addition of increasing quantities of the acetate anion. This enhancement in the emission intensity was assigned to the formation of the $\mathrm{Y}$-shaped hydrogen-bonding complex between the NH thiourea protons of the receptor and the acetate 25 anion. However in this case, no significant deprotonation occurred and no red-shifted absorptions or emission bands were observed.

\section{${ }^{1} \mathrm{H}-\mathrm{NMR}$ spectroscopic studies in the presence of anions.}

30 As seen previously, the UV-Vis and fluorescence data of thiosemicarbazone receptors 3a-f and $\mathbf{4}$ in the presence of anions displayed a varied response in the presence of anions related with the presence of hydrogen-bonding interactions and the deprotonation of the receptors. In particular, the colorimetric 35 behaviour observed for these receptors depends on the deprotonation tendencies of the thiosemicarbazone units in receptors 3a-f and $\mathbf{4}$ and on the proton affinities of the anions.

In order to study the coordination/deprotanation processes in these systems in more detail, the interaction of receptor $\mathbf{3 b}$ with 40 the fluoride anion was investigated by means of ${ }^{1} \mathrm{H}-\mathrm{NMR}$ titration experiments in DMSO- $\mathrm{d}_{6}$. Deuterated DMSO was selected as the solvent due to the poor solubility of $\mathbf{3 b}$ in deuterated acetonitrile.

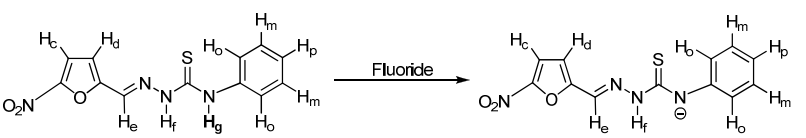

Scheme 2. Proposed mode for the fluoride-induced deprotonation of receptor $\mathbf{3 b}$.

The ${ }^{1} \mathrm{H}-\mathrm{NMR}$ spectrum of $\mathbf{3 b}$ showed the expected signals in the aromatic zone due to the presence of one benzene ring and one furan heterocycle. The monosubstituted benzene ring showed resonances at 7.21-7.26 $\left(1 \mathrm{H}\right.$, multiplet, $\left.\mathrm{H}_{\mathrm{p}}\right), 7.39(2 \mathrm{H}$, broad so triplet, $\left.\mathrm{H}_{\mathrm{m}}\right), 7.52-7.56\left(2 \mathrm{H}\right.$, multiplet, $\left.\mathrm{H}_{\mathrm{o}}\right)$ ppm, whereas the protons of the 1,4-disubstituted furan ring $\left(\mathrm{H}_{\mathrm{d}}\right.$ and $\left.\mathrm{H}_{\mathrm{c}}\right)$ appeared as a broad doublet at $7.50\left(\mathrm{H}_{\mathrm{d}}\right)$ and at $7.83\left(\mathrm{H}_{\mathrm{c}}\right)$ ppm. Finally, the imine proton $(-\mathrm{CH}=\mathrm{N})$ was a broad singlet at $8.08\left(\mathrm{H}_{\mathrm{e}}\right) \mathrm{ppm}$, and the $\mathrm{N}-\mathrm{H}$ protons of the thiosemicarbazone group were also broad s5 singlets at $10.18\left(\mathrm{H}_{\mathrm{g}}\right)$ and $12.23\left(\mathrm{H}_{\mathrm{f}}\right) \mathrm{ppm}$.

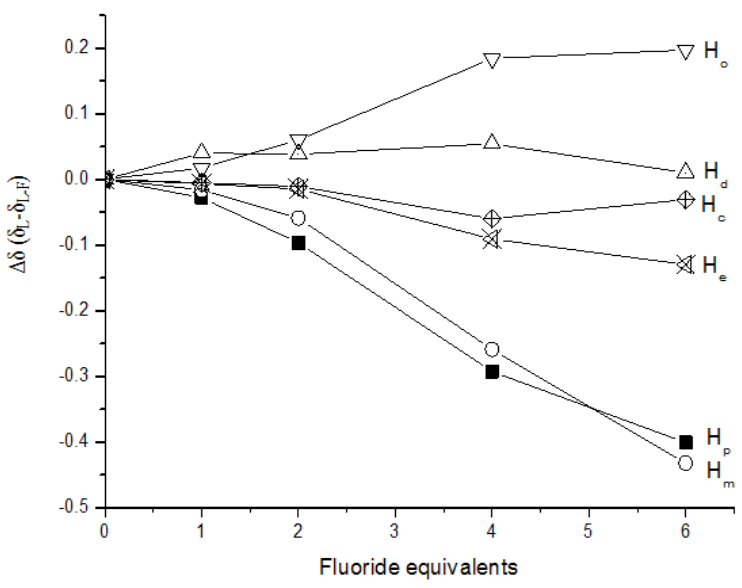

Figure 8. ${ }^{1} \mathrm{H}$ NMR shifts for the protons of receptor $\mathbf{3 b}$ in the presence of increasing quantities of the fluoride anion $\left(\mathrm{DMSO}-\mathrm{d}_{6}\right)$.

In a first step, we studied the shifts of the protons of receptor ${ }_{60} \mathbf{3 b}$ upon addition of increasing quantities of the fluoride anion. The most important fact was the disappearance of the $\mathrm{H}_{\mathrm{f}}$ and $\mathrm{H}_{\mathrm{g}}$ protons upon addition of 1 equivalent of fluoride. Additionally, 
the variation in the chemical shifts $\Delta \delta$ (ppm) for other protons in $\mathbf{3 b}$ during the titration with fluoride is shown in Figure 8.

As seen, protons $\mathrm{H}_{c}, \mathrm{H}_{\mathrm{d}}$ and $\mathrm{H}_{\mathrm{e}}$ showed negligible changes in their position in the NMR spectrum. In contrast, remarkable shifts 5 were noted for $\mathrm{H}_{\mathrm{o}}, \mathrm{H}_{\mathrm{m}}$ and $\mathrm{H}_{\mathrm{p}}$, suggesting that deprotonation took place in the N-H group closer to the phenyl group. It has been reported that upon the deprotonation of the N-H group, two effects might become active: (i) an increase in the electron density in the phenyl ring according to a $\pi$-mechanism, which 10 should induce a shielding effect (an upfield shift of the C-H signals is expected), and (ii) a polarization of the $\mathrm{C}-\mathrm{H}$ bonds induced by a through-space electrostatic mechanism, which is expected to cause a deshielding effect. Figure 8 shows how the $\mathrm{H}_{\mathrm{o}}$ protons underwent important downfield shifts, indicating 15 strong electrostatic effects due to the proximity of a negatively charged thiourea nitrogen atom. Protons $\mathrm{H}_{\mathrm{m}}$ and $\mathrm{H}_{\mathrm{p}}$ underwent upfield shifts as a result of the through-bond effect which, in this case, dominated (through-space effects vanished with distance). Fabbrizzi et. al. and ourselves have observed a similar behaviour 20 in closely related thioureas; i.e., deprotonation apparently occurred in the protons of the nitrogen attached to the phenyl ring. ${ }^{22}$

\section{Quantum Mechanical Studies.}

One way of describing the hydrogen bond-donating or -accepting 25 ability of a molecule in a particular group can be accessed by gasphase deprotonation energy studies determined by quantum chemical calculations by subtracting the energy of the receptor alone from that of the deprotonated form. For these studies, receptors 3a-f containing furyl heterocycles were selected in 30 order to obtain data that would be comparable. Calculations were carried out using a PM3 semi-empirical model. These thiosemicarbazone receptors contained two N-H groups and the deprotonation studies were performed by assuming that both protons could be eliminated. The data in Table 3 strongly suggest 35 that the most acidic one was that which was attached to the imine carbon directly bonded to the furyl heterocycle (the more negative the value of the difference, the stronger the hydrogenbond donor character). However, these results obtained from theoretical calculations contrast with the apparent conclusion of 40 the ${ }^{1} \mathrm{H}$ NMR titrations, which suggested that deprotonation occurred at the $\mathrm{H}_{\mathrm{g}}$ proton. The literature describes similar contradictory results obtained from the theoretical and experimental NMR data. ${ }^{14}$

Table 3. Stabilization Energy of the Deprotonation for Receptors

\begin{tabular}{ccc}
\hline \multirow{2}{*}{ Receptor } & \multicolumn{2}{c}{$\mathrm{E}_{(\mathrm{L})}-\mathrm{E}_{(\mathrm{LH})}(\mathrm{Kcal} / \mathrm{mol})$} \\
\cline { 2 - 3 } & $\mathrm{R}=\mathrm{N}-\mathrm{NH}-\mathrm{C}(\mathrm{S})-N-\mathrm{Ph}^{\mathrm{a}}$ & $\mathrm{R}=\mathrm{N}-\mathrm{N}-\mathrm{C}(\mathrm{S})-\mathrm{NH}-\mathrm{Ph}^{\mathrm{b}}$ \\
\hline 3a & -5.87 & -13.66 \\
3b & -5.18 & -14.56 \\
3c & -6.16 & -14.93 \\
3d & -6.35 & -14.33 \\
3e & -6.84 & -14.67 \\
3f & -10.20 & -18.86 \\
\hline
\end{tabular}

$45 \quad{ }^{\mathrm{a}}$ Deprotonation at the $\mathrm{H}_{\mathrm{g}}$ proton (see Scheme 2)

\section{${ }^{\mathrm{b}}$ Deprotonation at the $\mathrm{H}_{\mathrm{f}}$ proton (see Scheme 2)}

Despite this apparent contradiction, the theoretical calculations roughly agree with the chromogenic behaviour observed for the ${ }_{50}$ receptors. Among the compounds studied using a PM3 semiempirical model, we can observe that the presence of an extra phenyl ring next to the furyl moiety (compounds 3c-3f) made the receptors more acidic when compared with derivative 3a. Moreover, the quantum mechanical studies indicate that 55 derivative $3 \mathbf{f}$ was the most acidic one. In fact, the acidity of the studied receptors followed this order $\mathbf{3 f}>\mathbf{3} \mathbf{c} \sim \mathbf{3 e} \sim \mathbf{3 b} \sim \mathbf{3 d}>\mathbf{3 a}$ (see Table 3). Basically, these data are in agreement with the chromo-fluorogenic behaviour of the receptors and with the expected basicity of anions in acetonitrile (i.e., $\mathrm{F}^{-}>\mathrm{CN}^{-}>\mathrm{AcO}^{-}>$ ${ }_{60} \mathrm{H}_{2} \mathrm{PO}_{4}^{-}, \mathrm{Cl}^{-}, \mathrm{HSO}_{4}^{-}, \mathrm{SCN}^{-}, \mathrm{NO}_{3}^{-}, \mathrm{Br}^{-}, \mathrm{I}^{-}$). Thus, the most basic anions fluoride and cyanide induced substantial spectroscopic changes for all the receptors, whereas acetate generally showed more minor changes in the optical properties of the receptors.

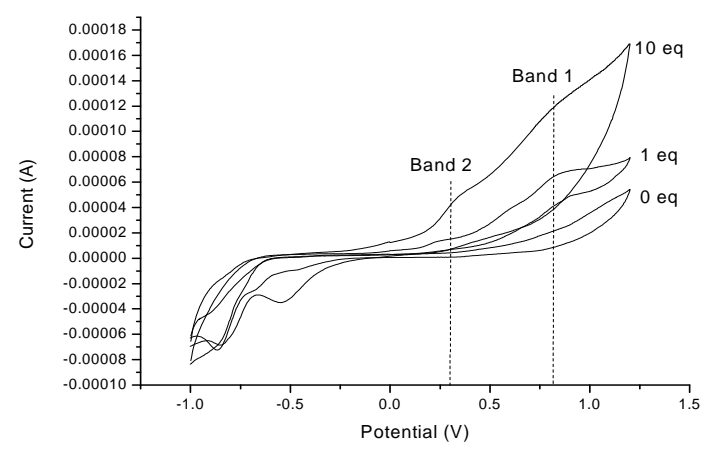

Figure 9. Cyclic voltammogram of receptor $3 \mathrm{~b}\left(5 \times 10^{-4} \mathrm{~mol} \mathrm{dm}^{-3}\right)$ in a 65 solution of $1 \times 10^{-2} \mathrm{~mol} \mathrm{dm}^{-3}\left[\mathrm{Bu}_{4} \mathrm{~N}\right]\left[\mathrm{ClO}_{4}\right] /$ acetonitrile alone (left) with 1 (centre) and 10 (right) equivalents of the fluoride anion at the scan rate of $20 \mathrm{mVs}^{-1}$.

\section{Electrochemical Studies in the Presence of Fluoride.}

70 The electrochemical behaviour of receptor $\mathbf{3 b}$ was studied alone $\left(5 \times 10^{-4} \mathrm{~mol} \mathrm{dm}^{-3}\right)$ and in the presence of the fluoride anion in acetonitrile using platinum as the working electrode and $\left[\mathrm{Bu}_{4} \mathrm{~N}\right]\left[\mathrm{ClO}_{4}\right]$ as the supporting electrolyte (see Figure 9). Receptor $\mathbf{3 b}$ showed a poorly defined irreversible oxidation band 75 sweeping to anodic potentials at $0.7 \mathrm{~V}$. Addition of $1 \mathrm{eq}$ of fluoride induced an intensity increase, a small shift of the original oxidation band (band 1) and the appearance of a new oxidation band (band 2) at $0.2 \mathrm{~V}$. Addition of $10 \mathrm{eq}$ of fluoride enhanced the intensity of both bands. The fact that band 1 did not 80 completely disappear with excess fluoride suggests the presence of a complex electrochemical mechanism involving both electrochemical and chemical reactions. 


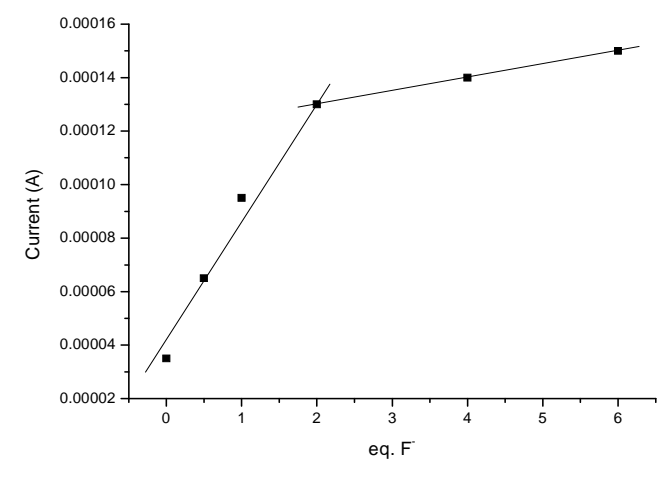

Figure 10. Current (A) of oxidation band 1 of $\mathbf{3 b}$ versus the equivalents of the fluoride added.

Moreover, Figure 10 shows the plot sowing the current of band 51 versus the equivalents of the fluoride added in $\mathbf{3 b}$ receptor. As observed, an almost linear increase took place up to 2 eq. This behaviour is in agreement with the fluoride reaction with $\mathbf{3 b}$, inducing deprotonation and the formation of the $\mathrm{F}_{2} \mathrm{H}^{-}$species.

\section{Conclusions}

10 A family of novel heterocyclic thiosemicarbazone containing furyl moieties (derivatives 3a-f and $\mathbf{4}$ ) has been prepared and characterized, and their interactions with anions have been studied via UV-Vis and fluorescence titrations, quantum chemical calculations and electrochemical techniques. The 15 thiosemicarbazone dyes show a modulation of their donor hydrogen-bonding abilities as a function of the electronic nature of the attached chemical groups. Two distinctive chromofluorogenic behaviours in the presence of anions in acetonitrile solutions are observed. The more basic anions fluoride and 20 cyanide are capable of inducing dual coordination-deprotonation for all the receptors studied, whereas acetate and dihydrogen phosphate display poorer coordination ability, and deprotonation is observed only upon the addition of large amounts of anion. Coordinative hydrogen-bonding interactions results in a slight 25 bathochromic shift, while deprotonation is indicated by the appearance of a new band at ca. 400-450 nm. The fluorescence studies evidence that hydrogen-bonding interactions become visible through the enhancement of the emission band, whereas deprotonation induces the appearance of a new red-shifted

30 emission. The PM3 studies are basically in agreement with the experimental behaviour. The electrochemical studies carried out with receptor $\mathbf{3 b}$ show an irreversible oxidation process at $0.7 \mathrm{~V}$, whereas the addition of fluoride also induces the growth of a new oxidation band at $0.2 \mathrm{~V}$. The observed response toward basic

35 anions of the receptors described in this paper clearly resembles the obtained with other derivatives containing hydrogen bonding binding sites (ureas, thiureas and amides). The selectivity trend is the same and only basic anions were able to induce a chromofluorgenic response. Despite the lack of response of these 40 receptors in aqueous environments, the ease of synthesis of thiosemicarbazones opens the possibility to design more complex and pre-organized neutral receptors for anions with enhanced selectivity and applicability in aqueous environment.

\section{Experimental Section}

\section{Materials and methods}

Thin-layer chromatography was carried out on $0.25 \mathrm{~mm}$ thick precoated silica plates (Merck Fertigplatten Kieselgel $60 \mathrm{~F}_{254}$ ). All the melting points were measured on a Gallenkamp melting point apparatus. NMR spectra were obtained on a Varian Unity Plus ${ }_{50}$ Spectrometer at an operating frequency of $300 \mathrm{MHz}$ for ${ }^{1} \mathrm{H}$ and $75.4 \mathrm{MHz}$ for ${ }^{13} \mathrm{C}$ or with a Bruker Avance III 400 at an operating frequency of $400 \mathrm{MHz}$ for ${ }^{1} \mathrm{H}$ and $100.6 \mathrm{MHz}$ for ${ }^{13} \mathrm{C}$, using the solvent peak as an internal reference. Solvents are indicated in parentheses before the chemical shift values ( $\delta$ relative to TMS ${ }_{55}$ and given in $\left.\mathrm{ppm}\right)$. The IR spectra were run on a FTIR PerkinElmer 1600 spectrophotometer in nujol. The elemental analyses were carried out on a Leco CHNS 932 instrument. Mass spectrometry analyses were performed at the C.A.C.T.I. - Unidad de Espectrometria de Masas of the University of Vigo, Spain, in a ${ }_{60}$ Hewlett Packard 5989 A spectrometer for low resolution spectra and in a VG Autospec M spectrometer for high resolution mass spectra. All the solvents were of spectrophotometrical grade. Air/water-sensitive reactions were performed in flame-dried glassware under argon. Aldehydes 1a-c, 1e-f and 4-phenyl-3${ }_{65}$ thiosemicarbazide $\mathbf{2}$ were purchased from Sigma-Aldrich and were used without further purification.

\section{General procedure for the synthesis of formyl-furans 1d and} $1 \mathrm{~g}$ through Suzuki cross-coupling

5-Bromofuran-2-carbaldehyde $(1.2 \mathrm{mmol})$ was coupled with 4 70 ethoxyphenylboronic acid or with 4-formylphenylboronic acid (1.6 mmol), in a mixture of DME $(15 \mathrm{~mL})$ and aqueous $2 \mathrm{M}$ $\mathrm{Na}_{2} \mathrm{CO}_{3}(1 \mathrm{~mL})$ and $\mathrm{Pd}\left(\mathrm{PPh}_{3}\right)_{4}(6 \mathrm{~mol} \%)$ at $80^{\circ} \mathrm{C}$ in an argon atmosphere for 5-12 h. After cooling, the mixture was filtered. Ethyl acetate and a saturated solution of $\mathrm{NaCl}$ were added and the 75 phases were separated. The organic phase was washed with water $(3 \times 50 \mathrm{~mL})$ and an aqueous solution of $\mathrm{NaOH}(10 \%)$. The organic phase obtained was dried $\left(\mathrm{MgSO}_{4}\right)$, filtered and solvent removal gave a crude mixture which was submitted to column chromatography on silica with increasing amounts of diethyl 80 ether in light petroleum as an eluent, thus affording the coupled products.

5-(4'-Ethoxyphenyl)furan-2-carbaldehyde (1d) ${ }^{15}$. Yellow solid (75\%). Mp: $120.1-122.3^{\circ} \mathrm{C}$. IR (Nujol) v $1670(\mathrm{C}=\mathrm{O}), 1608$, ${ }_{85} 1291,1254,1119,1041,1029,959,919,838,797,772 \mathrm{~cm}^{-1} .{ }^{1} \mathrm{H}$ NMR $\left(\mathrm{CDCl}_{3}\right) \delta 1.39\left(\mathrm{t}, 3 \mathrm{H}, J=7.2 \mathrm{~Hz}, \mathrm{CH}_{3}\right), 4.02(\mathrm{q}, 2 \mathrm{H}, J=7.2$ $\left.\mathrm{Hz}, \mathrm{CH}_{2}\right), 6.66(\mathrm{~d}, 1 \mathrm{H}, 3 \mathrm{H}, J=3.6 \mathrm{~Hz}, 4-\mathrm{H}), 6.89$ (dd, $2 \mathrm{H}, J=6.4$ and $2.0 \mathrm{~Hz}, \mathrm{H} 3$ ' and H5'), 7.25 (d, 1H, $J=3.6 \mathrm{~Hz}, \mathrm{H} 3$ ), 7.69 (dd, $2 \mathrm{H}, J=6.4$ and $2.0 \mathrm{~Hz}, \mathrm{H} 2$ ' and $\left.\mathrm{H} 6{ }^{\prime}\right), 9.54(\mathrm{~s}, 1 \mathrm{H}, \mathrm{CHO}) .{ }^{13} \mathrm{C}$ 90 NMR $\left(\mathrm{CDCl}_{3}\right) \delta 14.54\left(\mathrm{CH}_{3}\right), 63.46\left(\mathrm{CH}_{2}\right), 106.10(\mathrm{C} 4), 114.17$ (C3' and C5'), 121.38 (C5), 124.32 (C3), 126.78 (C2' and C6'), 151.37 (C2), 159.72 (C1'), 160.12 (C4'), 176.60 (CHO). MS (EI) $m / z(\%): 216\left(\mathrm{M}^{+}, 100\right), 188$ (93), 187 (35), 160 (33), 131 (43), 77 (17). HRMS: (EI) $\mathrm{m} / \mathrm{z}(\%)$ for $\mathrm{C}_{13} \mathrm{H}_{12} \mathrm{O}_{3}$; calcd 216.079; 95 found 216.078 .

5-(4'-Formylphenyl)furan-2-carbaldehyde (1g). Orange solid 
(91\%). Mp: 124.6-126.0 ${ }^{\circ} \mathrm{C}$. IR (Nujol) v 1659 (C=O), 1602, 1309, 1157, 1117, 1093, 1020, 966, 946, 810, $722 \mathrm{~cm}^{-1}$. ${ }^{1} \mathrm{H}$ NMR $\left(\mathrm{CDCl}_{3}\right) \delta 7.01(\mathrm{~d}, 1 \mathrm{H}, J=3.6 \mathrm{~Hz}, \mathrm{H} 4), 7.36(\mathrm{~d}, 1 \mathrm{H}, J=3.6 \mathrm{~Hz}$, H3), 7.98 (m, 4H, H2', H6', H3' and H5'), 9.72 (s, 1H, CHO), $510.05(\mathrm{~s}, 1 \mathrm{H}, \mathrm{CHO}) .{ }^{13} \mathrm{C} \mathrm{NMR}\left(\mathrm{CDCl}_{3}\right) \delta 110.0(\mathrm{C} 4), 123.0(\mathrm{C} 3)$, 125.6 (C2' and $\mathrm{C}^{\prime}$ '), 130.3 (C3' and $\mathrm{C}^{\prime}$ '), 134.1 (C1'), 136.5 (C4'), 152.7 (C2), 157.4 (C5), 177.5 (CHO), 191.3 (CHO). MS (EI) $\mathrm{m} / \mathrm{z}(\%): 200\left(\mathrm{M}^{+}, 100\right), 199$ (84), 171 (18), 143 (23), 115 (56). HRMS: (EI) $\mathrm{m} / \mathrm{z}(\%)$ for $\mathrm{C}_{12} \mathrm{H}_{8} \mathrm{O}_{3}$; calcd 200.047; found 10200.048 .

\section{General procedure for the synthesis of heterocyclic phenylthiosemicarbazones 3-4}

Equal amounts $(0.4 \mathrm{mmol})$ of the appropriate aldehyde and 15 thiosemicarbazide were dissolved in $\mathrm{MeOH}(30 \mathrm{~mL})$ at room temperature. A solution was obtained, which was stirred overnight. Compounds were precipitated as microcrystalline solids, and were collected by suction filtration, washed with cold $\mathrm{MeOH}$ and diethyl ether, then dried by vacuum. Further 20 recrystallizations using $\mathrm{CHCl}_{3}$ - petroleum ether mixtures were performed if necessary.

1-((5-Bromofuran-2-yl)methylene)-4-phenylthiosemicarbazone 3a was obtained as a yellow solid $(76 \%)$. Mp: $149.5-150.8{ }^{\circ} \mathrm{C} .{ }^{1} \mathrm{H}$ ${ }_{25}$ NMR (DMSO- $\left.d_{6}\right): \delta=6.76(\mathrm{~d}, J=3.9 \mathrm{~Hz}, 1 \mathrm{H}, \mathrm{H} 3$ ') 7.10 (d, $J=$ $3.9 \mathrm{~Hz}, 1 \mathrm{H}, \mathrm{H} 4$ '), 7.15-7.21 (m, 1H, H4), 7.34 (br t, $J=7.2 \mathrm{~Hz}$, 2H, H3 and H5), 7.55 (br d, $J=7.2 \mathrm{~Hz}, 2 \mathrm{H}, \mathrm{H} 2$ and $\mathrm{H} 6$ ), 7.99 (s, $1 \mathrm{H},-\mathrm{CH}=\mathrm{N}), 9.88(\mathrm{~s}, 1 \mathrm{H}, \mathrm{S}=\mathrm{C}-\mathrm{NH}), 11.85(\mathrm{~s}, 1 \mathrm{H}, \mathrm{C}=\mathrm{N}-\mathrm{NH})$ ppm. 13C NMR (DMSO-d $\left.{ }_{6}\right): \delta=114.5$ (C3'), 115.6 (C4'), 30124.3 (C5'), 125.3 (C4), 125.5 (C2 and C6), 128.1 (C3 and C5), $131.67(-\mathrm{CH}=\mathrm{N}), 138.9(\mathrm{C} 1), 151.4\left(\mathrm{C} 2^{\prime}\right), 175.8(\mathrm{C}=\mathrm{S}) \mathrm{ppm}$. IR (Nujol) $v 3332,3132,1593,1558,1538,1515,1448,1274,1266$, $1205,1125,1016,920,781,739,689 \mathrm{~cm}^{-1} \cdot \mathrm{C}_{12} \mathrm{H}_{10} \mathrm{BrN}_{3} \mathrm{OS}$ (322.97): calcd. C 44.46, H 3.11, N 12.96, S 9.89; found C: ${ }_{35} 44.33, \mathrm{H} 3.12$, N 12.93; S 9.81.

1-((5-Nitrofuran-2-yl)methylene)-4-phenylthiosemicarbazone $\mathbf{3 b}$ was obtained as a yellow solid (81\%). Mp: $188.0-188.7{ }^{\circ} \mathrm{C} .{ }^{1} \mathrm{H}$ NMR (DMSO- $d_{6}$ ): $\delta=7.20-7.25$ (m, 1H, H4), 7.38 (br t, $J=7.8$ ${ }_{40} \mathrm{~Hz}, 2 \mathrm{H}, \mathrm{H} 3$ and $\left.\mathrm{H} 5\right), 7.49-7.55$ (m, 3H, H3', H2 and H6), 7.82 (d, $\left.J=3.9 \mathrm{~Hz}, 1 \mathrm{H}, \mathrm{H} 4^{\prime}\right), 8.07$ (s, $\left.1 \mathrm{H},-\mathrm{CH}=\mathrm{N}\right), 10.18(\mathrm{~s}, 1 \mathrm{H}, \mathrm{S}=\mathrm{C}-$ $\mathrm{N} H$ ), 12.23 (s, $1 \mathrm{H}, \mathrm{C}=\mathrm{N}-\mathrm{N} H)$ ppm. ${ }^{13} \mathrm{C}$ NMR $\left(\mathrm{DMSO}-d_{6}\right): \delta=$ 113.5 (C3'), 115.2 (C4'), 125.7 (C4), 125.9 (C2 and C6), 128.2 $(\mathrm{C} 3$ and $\mathrm{C} 5), 130.2(-\mathrm{CH}=\mathrm{N}), 138.7(\mathrm{C} 1), 151.6(\mathrm{C} 5), 152.6$ ${ }_{45}\left(\mathrm{C}^{\prime}\right.$ '), $176.3(\mathrm{C}=\mathrm{S}) \mathrm{ppm}$. IR (Nujol) v 3313, 3135, 1554, 1529, 1514, 1344, 1251, 1188, 1098, 1015, 964, 810, 760, 741, $693 \mathrm{~cm}$ 1. $\mathrm{C}_{12} \mathrm{H}_{10} \mathrm{~N}_{4} \mathrm{O}_{3} \mathrm{~S}$ (290.05): calcd. C 49.65, H 3.47, N 19.30, S 11.05; found C: 49.24, H 3.53, N 19.18; S 11.11 .

50 4-Phenyl-1-((5-phenylfuran-2-yl)methylene)thiosemicarbazone 3c was obtained as a yellow solid $(76 \%)$. Mp: $176.0-176.8^{\circ} \mathrm{C} .{ }^{1} \mathrm{H}$ NMR (DMSO- $d_{6}$ ): $\delta=7.14$ (d, $J=3.3 \mathrm{~Hz}, 1 \mathrm{H}, \mathrm{H} 3{ }^{\prime}$ ), 7.18-7.23 (m, 2H, H4 and H4'), 7.32-7.47 (m, 5H, H3', H4', H5', H3 and H5), 7.58 (br d, $J=7.5 \mathrm{~Hz}, 2 \mathrm{H}, \mathrm{H} 2$ and H6), 7.83 (br d, $J=6.9$ ${ }_{55} \mathrm{~Hz}, 2 \mathrm{H}, \mathrm{H} 2$ ' 'and H6' '), 8.09 (s, 1H, -CH=N), 9.93 (s, 1H, S=C$\mathrm{NH}), 11.89$ (s, 1H, C=N-NH) ppm. 13C NMR (DMSO-d6): $\delta=$ 108.5 (C3'), 115.8 (C4'), 124.0 (C2'' and C6'), 125.3 (C4), 125.7 (C2 and C6), 128.1 (C3 and C5), 128.3 (C4'”), 129.0 (C3'”and
C5'), 129.5 (C1'”), $132.4(-\mathrm{CH}=\mathrm{N}), 139.0$ (C1), 148.9 (C5'), 60154.8 (C2'), 175.6 (C=S) ppm. IR (Nujol) v 3270, 3147, 1622, 1595, 1553, 1530, 1491, 1259, 1188, 1092, 1026, 980, 922, 908, 754, $685 \mathrm{~cm}^{-1} . \mathrm{C}_{18} \mathrm{H}_{15} \mathrm{~N}_{3} \mathrm{O}_{5} \mathrm{~S}$ (321.09): calcd. C 67.27, H 4.70, N 13.07, S 9.98; found C: 67.19, H 4.76, N 12.91; S 9.65.

\section{${ }_{65}$ 1-((5-(4-Ethoxyphenyl)furan-2-yl)methylene)-4-}

phenylthiosemicarbazone $\mathbf{3 d}$ was obtained as a yellow solid (78\%). Mp: $178.8-179.9^{\circ} \mathrm{C}$. $1 \mathrm{H} \mathrm{NMR} \mathrm{(DMSO-} d_{6}$ ): $\delta=1.32$ (t, $J$ $\left.=7.2 \mathrm{~Hz}, 3 \mathrm{H}, \mathrm{OCH}_{2} \mathrm{CH}_{3}\right), 4.05$ (q, J=7.2 Hz, $\left.2 \mathrm{H}, \mathrm{OC} \underline{H} 2 \mathrm{CH} 3\right)$, 6.96-7.01 (m, 3H, H3', H3' ' and H5' '), 7.13 (d, $J=3.6 \mathrm{~Hz}, 1 \mathrm{H}$, $70 \mathrm{H} 4$ '), 7.17-7.23 (m, 1H, H4), 7.37 (br t, $J=7.2 \mathrm{~Hz}, 2 \mathrm{H}, \mathrm{H} 3$ and H5), 7.58 (br d, $J=7.2 \mathrm{~Hz}, 2 \mathrm{H}, \mathrm{H} 2$ and H6), 7.76 (dd, $J=6.9$ and $2.1 \mathrm{~Hz}, 2 \mathrm{H}, \mathrm{H} 2$ " and H6"), $8.01(\mathrm{~s}, 1 \mathrm{H},-\mathrm{CH}=\mathrm{N}), 9.89$ (s, $1 \mathrm{H}, \mathrm{S}=\mathrm{C}-\mathrm{NH}), 11.84(\mathrm{~s}, 1 \mathrm{H}, \mathrm{C}=\mathrm{N}-\mathrm{NH}) \mathrm{ppm} .{ }^{13} \mathrm{C}$ NMR (DMSO$\left.d_{6}\right): \delta=14.6\left(\mathrm{OCH}_{2} \underline{\mathrm{CH}} \mathrm{H}_{3}\right), 63.2\left(\mathrm{O}_{\underline{C H}} \mathrm{CH}_{3}\right), 106.7\left(\mathrm{C} 3^{\prime}\right), 114.8$ 75 (C3' 'and C5'), 116.2 (C4'), 122.2 (C1'”), 125.3 (C4), 125.6 (C2 and C6), 125.7 (C2"'and C6"'), 128.1 (C3 and C5), 132.5 ($\mathrm{CH}=\mathrm{N}), 139.0$ (C1), 148.1 (C5'), 155.2 (C2'), 158.7 (C4'”), 175.5 $(C=S)$ ppm. IR (Nujol) v 3339, 3133, 1621, 1606, 1548, 1505, $1269,1251,1219,1176,1116,1037,975,919,833,786,740 \mathrm{~cm}^{-}$ ${ }_{80}{ }^{1} . \mathrm{C}_{20} \mathrm{H}_{19} \mathrm{~N}_{3} \mathrm{O}_{2} \mathrm{~S}$ (365.12): calcd. C 65.73, H 5.24, N 11.50, S 8.77; found C: 65.23 , H 5.21, N 11.49; S 8.69.

\section{1-((5-(4-Bromophenyl)furan-2-yl)methylene)-4-}

phenylthiosemicarbazone $3 \mathbf{e}$ was obtained as a yellow solid ${ }_{85}$ (87\%). Mp: $197.3-198.7^{\circ} \mathrm{C}$. $1 \mathrm{H}$ NMR (DMSO- $d_{6}$ ): $\delta=7.18-7.23$ (m, 3H, H3', H4' and H4), 7.37 (br t, $J=8.0 \mathrm{~Hz}, 2 \mathrm{H}, \mathrm{H} 3$ and H5), 7.58 (br d, 1H, $J=8.0 \mathrm{~Hz}, 2 \mathrm{H}, \mathrm{H} 2$ and H6), 7.63 (dd, $J=$ 6.4 and $2.0 \mathrm{~Hz}, 2 \mathrm{H}, \mathrm{H} 2$ "' and H6" ') 7.78 (dd, $J=6.4$ and $2.0 \mathrm{~Hz}$, 2H, H3" and H5"'), 8.08 (s, 1H, - CH=N), $9.92(\mathrm{~s}, 1 \mathrm{H}, \mathrm{S}=\mathrm{C}-\mathrm{NH})$, 9011.89 (s, 1H, C=N-NH) ppm. 13C NMR (DMSO-d $\left.d_{6}\right): \delta=109.2$ (C3'), 115.8 (C4'), 121.2 (C4'’), 125.3 (C4), 125.7 (C2 and C6), 125.9 (C3"' and C5"), 128.1 (C3 and C5), 128.6 (C1'), 131.9 (C2''and C6"'), $132.2(-\mathrm{CH}=\mathrm{N}), 139.0(\mathrm{C} 1), 149.3(\mathrm{C} 5$ '), 153.6 (C2'), 175.7 (C=S) ppm. IR (Nujol) v 3287, 3143, 1683, 1667, 95 1594, 1552, 1504, 1445, 1265, 1197, 1974, 1021, 1008, 926, 822, 785, 766, $735 \mathrm{~cm}^{-1}$. MS (ESI): $\mathrm{m} / \mathrm{z}(\%)=402\left(\mathrm{M}+\mathrm{H}+{ }^{81} \mathrm{Br}, 100\right)$, $400\left(\mathrm{M}+\mathrm{H}+{ }^{79} \mathrm{Br}, 100\right), 399(\mathrm{M}+, 82), 370$ (41), 368 (41). HRMS (ESI): calcd. for $\mathrm{C}_{18} \mathrm{H}_{15}{ }^{81} \mathrm{BrN}_{3} \mathrm{OS} 402.00929$, found 402.00905; calcd. for $\mathrm{C}_{18} \mathrm{H}_{15}{ }^{79} \mathrm{BrN}_{3} \mathrm{OS} 400.0114$, found 400.0111 .

100

\section{1-((5-(4-Nitrophenyl)furan-2-yl)methylene)-4-}

phenylthiosemicarbazone $3 f$ was obtained as a yellow solid (96\%). Mp: 205.4-206.8 ${ }^{\circ} \mathrm{C} .{ }^{1} \mathrm{H}$ NMR (DMSO- $d_{6}$ ): $\delta=7.19-7.25$ (m, 1H, H4), 7.28 (d, $J=3.9 \mathrm{~Hz}, 1 \mathrm{H}, \mathrm{H} 3$ '), 7.38 (br t, $J=7.8 \mathrm{~Hz}$, $1052 \mathrm{H}, \mathrm{H} 3$ and H5), 7.48 (d, $\left.J=3.9 \mathrm{~Hz}, 1 \mathrm{H}, \mathrm{H} 4{ }^{\prime}\right), 7.57$ (br d, $J=7.8$ $\mathrm{Hz}, 2 \mathrm{H}, \mathrm{H} 2$ and $\mathrm{H} 6), 8.05-8.11\left(\mathrm{~m}, 3 \mathrm{H}, \mathrm{H} 2{ }^{\prime}, \mathrm{H}^{\prime}\right.$ ' and $\left.-\mathrm{CH}=\mathrm{N}\right)$, 8.28 (dd, $J=7.2$ and $2.1 \mathrm{~Hz}, 2 \mathrm{H}, \mathrm{H} 3$ " ' and H5"), 9.99 (s, 1H, $\mathrm{S}=\mathrm{C}-\mathrm{N} H), 12.00(\mathrm{~s}, 1 \mathrm{H}, \mathrm{C}=\mathrm{N}-\mathrm{N} H) \mathrm{ppm} .{ }^{13} \mathrm{C} \mathrm{NMR}\left(\mathrm{DMSO}-d_{6}\right): \delta$ $=112.6$ (C3'), 115.7 (C4'), $124.4(\mathrm{C} 3$ '' and C5') 124.6 (C2' 'and ${ }_{110}$ C6"), 125.5 (C4), 125.8 (C2 and C6), 128.2 (C3 and C5), 131.8 $(-\mathrm{CH}=\mathrm{N}), 135.2\left(\mathrm{C} 1{ }^{\prime \prime}\right), 138.9(\mathrm{C} 1), 146.3\left(\mathrm{C} 4{ }^{\prime \prime}\right), 151.0(\mathrm{C} 5$ '), 152.4 (C2'), $175.8(C=S)$ ppm. IR (Nujol) v 3316, 3135, 1600, 1592, 1552, 1510, 1341, 1265, 1212, 1201, 1114, 1084, 1029, 809, 849, 798, 711, 693, $637 \mathrm{~cm}^{-1} . \mathrm{C}_{18} \mathrm{H}_{14} \mathrm{~N}_{4} \mathrm{O}_{3} \mathrm{~S}$ (366.08): calcd. ${ }_{115} \mathrm{C} 59.01, \mathrm{H} 3.85, \mathrm{~N} 15.29, \mathrm{~S} 8.75$; found C: $58.39, \mathrm{H} 3.92, \mathrm{~N}$ $15.25 ; \mathrm{S} 8.77$. 


\section{1,1-((5-Phenylfuran-2-yl)methylene)-bis-4-}

phenylthiosemicarbazone 4 was obtained as a yellow solid $(90 \%)$. Mp: 203.9-204.8 ${ }^{\circ} \mathrm{C} .{ }^{1} \mathrm{H}$ NMR (DMSO- $\left.d_{6}\right): \delta=7.18-7.23(\mathrm{~m}$, 5 3H, 2 x (H4 and H4')), 7.27 (d, $J=3.6 \mathrm{~Hz}, 1 \mathrm{H}, \mathrm{H} 3$ '), 7.37 (br t, $J$ $=7.9 \mathrm{~Hz}, 4 \mathrm{H}, 2 \times(\mathrm{H} 3$ and $\mathrm{H} 5)), 7.55-7.62(\mathrm{~m}, 4 \mathrm{H}, 2 \times(\mathrm{H} 2$ and H6)), 7.88 (d, $J=8.4 \mathrm{~Hz}, 2 \mathrm{H}, \mathrm{H} 2$ ' ' and H6' '), 7.97 (d, $J=8.4 \mathrm{~Hz}$, $2 \mathrm{H}, \mathrm{H} 3$ " and H5'), $8.10(\mathrm{~s}, 1 \mathrm{H},-\mathrm{CH}=\mathrm{N}), 8.16(\mathrm{~s}, 1 \mathrm{H},-\mathrm{CH}=\mathrm{N})$, $9.96(\mathrm{~s}, 1 \mathrm{H}, \mathrm{S}=\mathrm{C}-\mathrm{NH}), 10.15(\mathrm{~s}, 1 \mathrm{H}, \mathrm{S}=\mathrm{C}-\mathrm{NH}), 11.86(\mathrm{~s}, 1 \mathrm{H}$, $\left.{ }_{10} \mathrm{C}=\mathrm{N}-\mathrm{NH}\right), 11.91(\mathrm{~s}, 1 \mathrm{H}, \mathrm{C}=\mathrm{N}-\mathrm{NH}) \mathrm{ppm} .{ }^{13} \mathrm{C}$ NMR $\left(\mathrm{DMSO}-d_{6}\right): \delta$ $=109.7$ (C3'), 115.9 (C4'), 124.1 (C2'"and C6'), 125.3 (C4), $125.4(\mathrm{C} 4), 125.5$ (C2 and $\mathrm{C} 6), 126.0$ (C2 and $\mathrm{C} 6), 128.0$ (C3 and C5), 128.1 (C3 and C5), 128.2 (C3' 'and C5'), 130.5 (C1''), $132.2(-\mathrm{CH}=\mathrm{N}), 133.7$ (C4'), $138.9(\mathrm{C} 1), 139.0(\mathrm{C} 1), 142.2$ ($\left.{ }_{15} \mathrm{CH}=\mathrm{N}\right), 149.4\left(\mathrm{C}^{\prime}\right), 154.3\left(\mathrm{C}^{\prime}\right), 175.6(C=\mathrm{S}), 176.0(C=\mathrm{S})$ ppm. IR (Nujol) $v$ 3322, 3300, 3158, 1598, 1559, 1524, 1449, 1329, 1261, 1195, 1096, 1024, 943, 919, 747, $693 \mathrm{~cm}^{-1}$. MS (ESI): $\mathrm{m} / \mathrm{z}(\%)=499(\mathrm{M}+\mathrm{H}+, 100), 467$ (24), 437 (14), 415 (25), 350 (16), 298 (9). HRMS (ESI): calcd. for $\mathrm{C}_{26} \mathrm{H}_{22} \mathrm{~N}_{6} \mathrm{OS}_{2}$ 20499.1369 , found 499.1364 .

\section{Spectroscopic Studies}

Stock solutions of the anions $\left(\mathrm{F}^{-}, \mathrm{Cl}^{-}, \mathrm{Br}^{-}, \mathrm{I}^{-}, \mathrm{NO}_{3}^{-}, \mathrm{H}_{2} \mathrm{PO}_{4}^{-}\right.$, $\mathrm{HSO}_{4}^{-}, \mathrm{AcO}^{-}, \mathrm{BzO}^{-}, \mathrm{CN}^{-}$as tetrabutylammonium salts) were prepared at $10^{-2}$ and $10^{-3} \mathrm{~mol} \mathrm{\textrm {dm } ^ { - 3 }}$ in acetonitrile. The 25 concentrations of ligands used in these measurements were ca.

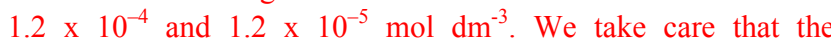
maximum addition of anion solutions did not exceed 5\% of the volume of the receptor to avoid significant changes in the solution concentration. Only in those experiments in which were 30 necessary to add an excess of anion (50 equiv.) corrections of concentration by volume were made. The UV-visible titrations were carried out at room temperature $\left(\sim 25^{\circ} \mathrm{C}\right)$

In fluorimetric titrations, all receptors were excited in wavelength of the pseudo-isosbestic points observed in the course 35 of UV-Vis titrations with fluoride anion. The electronic absorption spectra were obtained on a Perkin Elmer Instruments Lambda $35 \mathrm{UV} /$ visible spectrometer and fluorescence spectra were recorded on a Quanta Master 40 steady state fluorescence spectrofluorometer from Photon Technology Internation (PTI); 40 all in quartz cuvettes $(1 \mathrm{~cm}) .{ }^{1} \mathrm{H}-\mathrm{NMR}$ titrations spectra were acquired with Varian 300 spectrometer.

Electrochemical studies were carried out in GPES V 4.9 Autolab 30 system using platinum as the working and reference electrodes, a $\left[\mathrm{Bu}_{4} \mathrm{~N}\right]\left[\mathrm{ClO}_{4}\right]$ solution $\left(1.0 \times 10^{-2} \mathrm{~mol} \mathrm{dm}^{-3}\right)$ as the 45 supporting electrolyte and a scan rate of $20 \mathrm{mVs}^{-1}$ in a thermostated cell at $25^{\circ} \mathrm{C}$.

\section{Theoretical studies}

Quantum chemical calculations at the semi-empirical level (PM3, ${ }_{50}$ within restricted Hartree-Fock level) were carried out in vacuum with the aid of Hyperchem V6.03. The Polar-Ribiere algorithm was used for optimization. The convergence limit and the RMS gradient were set to $0.01 \mathrm{kcal} \mathrm{mol}^{-1}$. Stability constants were estimated with the HypSpec Software V1.1.18 using the data of ${ }_{5 s}$ the titration of receptors with selected anions.

\section{Acknowledgments}

We thank the Spanish Government (project MAT2009-14564C04-01) and the Generalitat Valenciana (project PROMETEO/2009/016) for support. We are also grateful to the ${ }_{60}$ Fundação para a Ciência e Tecnologia (Portugal) and FEDERCOMPETE for financial support through the Centro de Química Universidade do Minho, Project PEst-C/QUI/UI0686/2011 (FCOMP-01-0124-FEDER-022716) and a Post-doctoral grant to R.M.F. Batista (SFRH/BPD/79333/2011). The NMR ${ }_{65}$ spectrometer Bruker Avance III 400 is part of the National NMR Network and was purchased within the framework of the National Program for Scientific Re-equipment, with funds from FCT. The authors are also indebted to the programme "Acções Integradas Luso-Espanholas/CRUP", for bilateral agreement 70 number E-144/10. Thanks also go to the Fundación Carolina and UPNFM-Honduras for a doctoral grant to L.E. Santos-Figueroa and the Spanish Ministry of Science and Innovation for an FPU grant to M.E. Moragues.

\section{Notes and references}

751 (a) L. Basabe-Desmonts, D. N. Reinhoudt, M. Crego-Calama, Chem. Soc. Rev., 2007, 36, 993-1017; (b) J. H. R. Tucker, Supramolecular Chemistry: From Molecules to Nanomaterials, (P. A. Gale, J. W. Steed Ed.2012, 5, 2523-2537; (c) R.Martínez-Máñez, F. Sancenón, M. Hecht, M. Biyikal, K. Rurack, Anal Bional Chem., 2011, 399, 55-

8074 ; (d) S. Karuppannan, J.-C. Chambron, Chem. As. J., 2011, 6, 964 984

2 (a) V. Amendola, M. Bonizzoni, D. Estebán-Gómez, L. Fabbrizzi, M. Licchelli, F. Sancenón, A. Taglietti, Coord. Chem. Rev., 2006, 250, 1451-1470; (b) C. Suksai, T. Tuntulani, Chem. Soc. Rev., 2003, 32, 192-202.

3 (a) E. M. Nolan, S. J. Lippard, Chem. Rev., 2008, 108, 3443-3480; (b) M. Formica, V. Fusi, L. Giorgi, M. Micheloni, Coord. Chem. Rev., 2012, 256, 170-192; (c) P. Pallavicini, Y. A. Diaz-Fernandez, L. Pasotti, Coord. Chem. Rev., 2009, 253, 2226-2240.

904 (a) R. Martínez-Máñez, F. Sancenón, Chem. Rev., 2003, 103, 4419 4476; (b) M. E. Moragues, R. Martínez-Máñez, F. Sancenón, Chem. Soc. Rev., 2011, 40, 2593-2643; (c) R.Martínez-Máñez, F. Sancenón, M. Biyikal, M. Hecht, K. Rurack, J. Mater. Chem., 2011, 21, 12588 12604.

955 (a) R. Martínez-Mañéz, F. Sancenón; Coord. Chem. Rev., 2006, 250, 3081-3093; (b) A. P. Davis, Coord. Chem. Rev., 2006, 250, 2939. 2951; (c) E. García-España, P. Díaz, J. M. Llinares, A. Bianchi, Coord. Chem. Rev., 2006, 250, 2952-2986; (d) E. A. Katayev, Y. A Ustynyuk, J. L. Sessler, Coord. Chem. Rev., 2006, 250, 3004-3037.

1006 (a) P. A. Gale, Acc. Chem. Res., 2006, 39, 465-475; (b) J. Yoon, S. K. Kim, N. J. Singh, K. S. Kim, Chem. Soc. Rev., 2006, 35, 355-360; (c) P. Blondeau, M. Segura, R. Pérez-Fernández, J. de Mendoza, Chem. Soc. Rev., 2007, 36, 198-210.

7 (a) F. Li, S. Carvalho, R. Delgado, M. G. B. Drew, V. Félix, Dalton 105 Trans., 2010, 39, 9579-9587; (b) Y. -S. Lin, G. -M. Tu, C. -Y. Lin, Y. -T. Chang, Y. -P. Yen, New J. Chem., 2009, 33, 860-867.

8 For recent papers of thiourea-based anion receptors see: (a) D. Makuc, J. R. Hiscock, M. E. Light, P. A. Gale, J. Plavec, Beils. J. Org. Chem., 2011, 7, 1205-1214; (b) Y. -S. Lin, J. -X. Zheng, Y. -

110 K. Tsui, Y. -P. Yien, Spectrochim. Acta, Part A, 2011, 79, 1552 1558; (c) M. O. Odago, D. M. Colabello, A. J. Lees, Tetrahedron, 2010, 66, 7465-7471; (d) P. A. Gale, S. E. García-Garrido, J. Garric, Chem. Soc. Rev., 2008, 37, 151-190; (e) S. Devaraj, D Saravanakumar, M. Kandaswamy, Sensors Act. B Chem., 2009, 136 13-19; (f) Z. Li, F. -Y. Wu, L. Guo, A. -F. Li, Y. B. Jiang, J. Phys. Chem. B, 2008, 112, 7071-7079; (g) J. V. Ros-Lis, R. MartínezMáñez, F. Sancenón, J. Soto, K. Rurack, H. Weißhoff, Eur. J. Org. Chem., 2007, 17, 2449-2458.

9 For recent examples see: (a) J. Krishnamurthi, T. Ono, S. Amemori, H. Komatsu, S. Shinkai, K. Sada, Chem. Commun., 2011, 47, 15711573; (b) P. Piątek, Chem. Commun., 2011, 47, 4745-4747; (c) X. 
He, F. Herranz, E. C. -C. Cheng, R. Vilar, V. W. -W. Yam, Chem. Eur. J., 2010, 16, 9123-9131.

10 (a) D. Esteban-Gómez, L. Fabbrizzi, M. Licchelli, J. Org. Chem., 2005, 70, 5717-5720; (b) L. S. Evans, P. A. Gale, M. E. Light, R. 5 Quesada, New J. Chem., 2006, 30, 1019-1025; (c) L. S. Evans, P. A Gale, M. E. Light, R. Quesada, Chem. Commun., 2006, 965-967; (d) G. Jakab, C. Tancon, Z. Zhang, K. M. Lippert, P. R. Schreiner, Org. Lett., 2012, 14, 1724-1727.

11 (a) S. P. G. Costa, R. M. F. Batista, P. Cardoso, M. Belsley, M. M.

$10 \quad$ M. Raposo, Eur. J. Org. Chem. 2006, 17, 3938-3946; (b) R. M. F. Batista, S. P. G. Costa, M. Belsley, M. M. M. Raposo, Tetrahedron, 2007, 63, 4258-4265; (c) M. M. M. Raposo, M. C. R. Castro, P. Schellenberg, A. M. C. Fonseca, M. Belsley, Tetrahedron 2011, 67, 5189-5198; (d) D. Collado, J. Casado, S. R. González, J. T. López

15 Navarrete, R. Suau, E. Perez-Inestrosa, T. M. Pappenfus, M. M. M. Raposo, Chem. Eur. J. 2011, 17, 498-507.

12 (a) J. Withnall, J. Howard, P. Ponka, D. R. Richardson, Proc. Natl. Acad. Sci. USA 2006, 103, 14901-14906; (b) H. -J. Zhang, X. Qin, K. Liu, D. -D. Zhu, X. -M. Wang, H. L. Zhu, Bioorg. Med. Chem. 2011, 19, 5708-5715.

13 (a) Y. -P. Tian, C. - Y. Duan, C. - Y. Zhao, X. -Z. You, Inorg. Chem., 1997, 36, 1247-1252; (b) R. Ramachandran, M. Rani, S. Kabilan, Bioorg. Med. Chem., 2009, 19, 2819-2823.

14 (a) M. M. M. Raposo, B. García-Acosta, T. Ábalos, P. Calero, R. Martínez-Máñez, J. V. Ros-Lis, J. Soto, J. Org. Chem., 2010, 75, 2922-2933; (b) V. Amendola, M. Boiocchi, L. Fabbrizzi, L. Mosca, Chem. Eur. J., 2008, 14, 9683-9696.

15 A. Mitsch, P. Wissner, K. Silber, P. Haebel, I. Sattler, G. Klebe, M. Schlitzer, Bioorg. Med. Chem., 2004, 12, 4585-4600.

3016 For recent examples see: (a) A. Aldrey, C. Núñez, V. García, R Bastida, C. Lodeiro, A. Macías, Tetrahedron, 2010, 66, 9223-9230; (b) A. K. Atta, I. -H. Ahn, A. -Y. Hong, J. Heo, C. K. Kim, D. -G. Cho, Tetrahedron Lett., 2012, 53, 575-578; (c) V. Amendola, L. Fabbrizzi, L. Mosca, F. -P. Schmidtchen, Chem. Eur. J., 2011, 17,

35 5972-5981; (d) V. Amendola, G. Bergamaschi, M. Boiocchi, L. Fabbrizzi, M. Milani, Chem. Eur. J., 2010, 16, 4368-4380.

17 For recent examples see: (a) T. H. Kim, M. S. Choi, B. -H. Sohn, S -Y. Park, W. S. Lyoo, T. S. Lee, Chem. Commun., 2008, 2364-2366; (b) V. Amendola, L. Fabbrizzi, Chem. Commun., 2009, 513-531; (c)

40 C. Caltagirone, A. Mulas, F. Isaia, V. Lippolis, P. A. Gale, M. A Light, Chem. Commun., 2009, 6279-6281; (d) C. Pérez-Casas, A. K. Yatsimirsky, J. Org. Chem., 2008, 73, 2275-2284; (e) C. M. G. dos Santos, T. McCabe, G. W. Watson, P. E. Kruger, T. Gunnlaugsson, J. Org. Chem., 2008, 73, 9235-9244; (f) P. Dydio, T. Zielinski, J.

45 Jurczak, J. Org. Chem., 2009, 74, 1525-1530; (g) Z. Xu, S. K. Kim, S. J. Han, C. Lee, G. Kociok-Kohn, T. D. James, J. Yoon, Eur. J. Org. Chem., 2009, 3058-3065

18 V. Amendola, D. Esteban-Gómez, L. Fabbrizzi, M. Licchelli, Acc. Chem. Res., 2006, 39, 343-353.

5019 M. Boiocchi, L. Del Boca, D. Estebán-Gómez, L. Fabbrizzi, M. Licchelli, E. Monzani, J. Am. Chem. Soc. 2004, 126, 16507-16514.

20 M. Boiocchi, L. Del Boca, D. Estebán-Gómez, L. Fabbrizzi, M. Licchelli, E. Monzani, Chem. Eur. J. 2005, 11, 3097-3104.

21 D. Esteban-Gómez, L. Fabbrizzi, M. Licchelli, E. Monzani, Org. Biomol. Chem. 2005, 3, 1495-1500.

22 M. Bonizzoni, L. Fabbrizzi, A. Taglietti, F. Tiengo, Eur. J. Org Chem., 2006, 3567-3574. 